\title{
Broj Hrvata u Crnoj Gori prema popisima stanovništva 1948. - 2011.
}

DOI: https://doi.org/10.11567/met.37.1.4 UDK: 314.117-054.51(497.16=163.42)“1948/2011“" 323.15(497.16=163.42)“1948/2011“" Izvorni znanstveni rad Primljeno: 25.05.2021. Prihvaćeno: 22.09.2021.

Saša Mrduljaš

Institut društvenih znanosti »Ivo Pilar« - Područni centar Split, Split

Sasa.Mrduljas@pilar.hr

\section{SAŽETAK}

Hrvati na tlu Crne Gore predstavljaju autohtono stanovništvo koje tradicionalno obitava u Boki Kotorskoj, Budvi te Baru i njegovoj okolici. Glavnina tog prostora do 1918. pripadala je austrijskoj, većinski hrvatskoj Kraljevini Dalmaciji, unutar koje je konstitucija slavenskoga katoličkog stanovništva u hrvatskome nacionalnom smislu bila u potpunosti ili gotovo dovršena do početka 20. stoljeća. Od nastanka Kraljevine Srba, Hrvata i Slovenaca, tj. Jugoslavije hrvatska populacija na tlu današnje Crne Gore, koja tada približno broji između 11.500 i 12.000 ljudi, trajno je izdvojena iz prevladavajuće hrvatskoga političko-socijalnog ambijenta i uklopljena u društveni okvir koji je do danas, unatoč državnoj neovisnosti Crne Gore, u bitnome determiniran srpskim političkim utjecajem. U tim uvjetima, sukladno opterećenosti hrvatskosrpskih odnosa, znatan dio hrvatske populacije na prostoru Crne Gore postupno se distancira od identifikacije s nacionalnim hrvatstvom prihvaćajući druge oblike izjašnjavanja. U ovom radu prezentirat će se i analizirati broj Hrvata na razini Crne Gore i njezinih administrativnih jedinica (srezovi, općine) u razdoblju od prvog popisa koji uključuje nacionalnu odrednicu provedenog 1948. do posljednjega iz 2011. U kontekstu popisa iz 2011. pokušat će se utvrditi i koliki bi bio broj, uvjetno rečeno hrvatskog življa u Crnoj Gori koji se te godine nije izjasnio u hrvatskome nacionalnom smislu.

KLJUČNE RIJEČI: Hrvati, Crna Gora, Kraljevina Dalmacija, Jugoslavija, popisi stanovništva

\section{UVOD}

Na početku rada koji se odnosi na broj Hrvata u Crnoj Gori potrebno je istaknuti određene činjenice koje su važne za ukupnu hrvatsku zajednicu te posebice za njezine rubne segmente. ${ }^{1}$ Naime, hrvatska nacionalna samo-

1 Ovaj rad nastao je je u okviru znanstveno-istraživačkog projekta Nacionalna identifikacija u Crnoj Gori (Znanstveno-istraživački projekti Instituta društvenih znanosti »Ivo Pilar« /2020. - 2022./). 
svijest rezultat je procesa koji su se kao i u ostatku Europe uglavnom odvili tijekom 19. i 20. stoljeća, kada su stvoreni društveni uvjeti prikladni za postojanje nacija (Stančić, 2002). Ta je samosvijest oblikovana na narodnosnoj podlozi unutar koje je hrvatsko ime postupno steklo dominantnu političkoidentifikacijsku važnost, no čije je temeljno obilježje da je stoljećima funkcionirala kao posebna kulturna cjelina, različita od ostatka svijeta po svome jeziku, a od susjednih i uvjetno rečeno istojezičnih pravoslavaca i muslimana po katoličkoj vjeri.

Ta prepoznatljiva jezično-vjerska formacija i u povijesnom i u suvremenom kontekstu bila je šira od zajednice uočljive po hrvatskom nazivu. Osim Hrvata njezinim historijskim dijelom bili su katolički Slavonci, Bošnjani, Neretvani, Zahumljani, Travunjani, Dukljani, Dalmatinci, Dubrovčani itd. S druge strane, nacionalnoformativni procesi nikada nisu doveli do toga da se svi pripadnici te jezično-vjerske formacije identificiraju kao nacionalni Hrvati. Već u samoj Hrvatskoj takvih je odstupanja bilo npr. u korist jugoslavenstva ili regionalnih odrednica. U sredinama gdje prevladavaju Srbi, Bošnjaci i Crnogorci, tj. u Srbiji, BiH i Crnoj Gori, takva su odstupanja izrazitija, prvenstveno zbog političke opterećenosti ovdašnjih međunacionalnih odnosa.

Premda se u hrvatskom društvu najčešće sve pripadnike navedene jezičnovjerske cjeline, neovisno o povijesnim okolnostima i nacionalnom izjašnjavanju, identificira kao Hrvate, u ovom radu takav je pristup neprimjeren s obzirom na predmet razmatranja. U njemu se primarno bavimo utvrđivanjem i analizom broja Hrvata u Crnoj Gori općenito te na razini njezinih administrativnih jedinica koristeći se podacima popisa stanovništva provedenih između 1948. i 2011. Stoga ćemo Hrvatima moći označiti samo osobe koje su se takvima i izjašnjavale. No značajni dio populacije koja se u popisima 1953., 1961. i 1971. izjašnjavala Hrvatima naknadno se očitovao drugačije. Jednako tako dio pripadnika te iste, šire jezično-vjerske zajednice kojoj pripadaju i Hrvati nije se ni u jednom od dosadašnjih popisa izjasnio u hrvatskome nacionalnom smislu.

U drugom dijelu rada, u kontekstu popisa iz 2011., cilj je bio da osim broja Hrvata utvrdimo i broj pripadnika jezično-vjerske zajednice kojoj uz Hrvate pripadaju i osobe koje se nisu tako izjasnile. Stoga je za potrebe rada bilo nužno odrediti termin kojim bi se imenovala ta jezično-vjerska cjelina. Tu smo se poslužili određenim lingvističkim rješenjem. U lingvistici se jezični sustav međusobno razumljivih govora lociranih između područja slovenskog i područja bugarskog te makedonskog jezika naziva središnjim 
južnoslavenskim dijasistemom (Lisac, 1996: 9). Sukladno tome, slavensku populaciju koja se izvorno koristi govorima tog dijasistema uopćeno bi se moglo nazvati Slavenima središnjega južnoslavenskog prostora (dalje: Slaveni sred. js. prostora) (»područje srednjojužnoslavenskog /ranijom terminologijom: hrvatskosrpskog-srpskohrvatskog/ jezičnog kontinuuma«, Stančić, 2002: 89). Pritom je smisleno katolički segment te populacije nazvati Slavenima katolicima sred. js. prostora ili, za potrebe rada, u kraćoj formi »Slaveno-katolicima«, što je, uz ostalo, i u određenoj opreci prema »Slaveno-pravoslavcima« i »Slaveno-muslimanima« sred. js. prostora.

U pojedinim slučajevima spomenutu i njoj oprečne odrednice upotrebljavat ćemo prilikom opisa povijesnog razvoja ovdašnjih etničkih suodnosa i identiteta, a posebice, kako je naznačeno, $u$ analizi koja se odnosi na popis 2011., jer neovisno o tome jesu li se pripadnici autohtonoga slavenskoga katoličkog življa u Crnoj Gori prilikom provođenja popisa nacionalno izjašnjavali Hrvatima ili kako drugačije, svi oni zajedno pripadaju jednoj jezično-vjerskoj cjelini s posebnim povijesnim iskustvom. Ujedno, na lokalnoj su razini dijelom istog ambijenta, istih naselja, pa i obitelji. Stoga ako već postoje metodološki ispravni razlozi da tu cjelinu ne nazovemo hrvatskim imenom, postoje i opravdani razlozi da je sagledamo u njezinoj potpunosti, upravo pod politički neutralnim imenom Slaveno-katolici, koji ne dovodi u pitanje ničiju nacionalnu identifikaciju.

\section{POVIJESNI OKVIR HRVATSKOG IDENTITETA NA TLU CRNE GORE}

Etnonimna funkcija hrvatskog imena na tlu današnje Crne Gore može se dovesti u vezu s najranijim razdobljima slavenske nazočnosti na ovdašnjim prostorima. Prema djelu bizantskog cara Konstantina Porfirogeneta (945. 959.) O upravljanju carstvom, Hrvati su prilikom doseljenja početkom 7. stoljeća zauzeli nekadašnju rimsku provinciju Dalmaciju (koja je, prema Porfirogenetovim predodžbama, »počinjala od okoline Drača, odnosno od Bara i prostirala se sve do istarskog gorja a u širinu je zahvaćala do rijeke Dunav «) te Panoniju i Ilirik (Vizantijski izvori..., 1959: 27-28, 31). Prema Ljetopisu popa Dukljanina (dalje: LJPD), koji je vjerojatno napisao barski (nad)biskup Grgur između 1177. i 1189., nakon što su se doselili, Slaveni su uspostavili državu čija je okosnica bila u primorju između Istre i sjevera današnje Albanije (Peričić, 1991). Prema LJPD-u, taj se pojas dijelio na Bijelu i Crvenu Hrvatsku koja se prostirala od Duvanjskog polja prema jugu (Ljetopis..., 1988). Tako- 
đer, bizantski pisci 11. i 12. stoljeća spominju Hrvate i Hrvatsku u kontekstu prostora današnje Crne Gore (Kulišić, 1980).

No u etnonimnom smislu južni dio istočnoga jadranskog priobalja (dio Dalmacije, Hercegovina i glavnina Crne Gore) kao i njegova zaleđa, odnosno dijelovi današnje Bosne približno između Vrbasa i Drine, nisu bili jednoznačni. Porfirogenet navodi da su se nakon Hrvata u (istočni) dio nekadašnje rimske provincije Dalmacije doselili Srbi naseljavajući između ostaloga i primorska područja između današnjeg Omiša i Kotora (Vizantijski izvori..., 1959). Prema LJPD-u, zaleđe »Kraljevstva Slavena« nazivalo se Zagorjem ili Srbijom te se tokom (gornje) Drine dijelilo na Bosnu i Rašku (Ljetopis..., 1988: 113-114). Bizantski pisci 11. i 12. stoljeća južni dio jadranskog priobalja dovode i u vezu s etnonimnom ulogom srpskog imena (Vizantijski izvori..., 1966).

I u hrvatskom i u srpskom slučaju riječ je o zanimljivim i bitnim podacima bez kojih slika o etničkim suodnosima unutar navedenog pojasa nije potpuna. No toj slici ipak temeljnu važnost daje samosvojni politički razvoj krajeva južnog primorja otkada se on može pratiti, tj. od početka 9. stoljeća. Izvjesno je da su između Cetine i Bojane postojale četiri slavenske kneževine: Neretva od Omiša do istoimene rijeke, zatim Zahumlje do Dubrovnika, Travunija do Kotora i Duklja do Bara i Skadra (Vizantijski izvori..., 1959). Izvjesno je i to da je u srednjovjekovlju presudni poticaj etničkoj identifikaciji došao iz pripadnosti tadašnjim državnim tvorevinama (Živković, 2012). U tom smislu vrlo je bitno da je polovinom 11. stoljeća inicijativom dukljanskih vladara došlo do državnog objedinjavanja Duklje, Travunije i Zahumlja. Ta proširena dukljanska država, kojom će vladati dinastija Vojislavljevića, stekla je međunarodnu afirmaciju time što ju je papinstvo priznavalo za zasebnu kraljevinu te snažnu polugu održanja vlastite samobitnosti očitovanu u postojanju državnoga vjerskog centra u vidu katoličke barske metropolije (Marković, 2014). Takav razvoj mogao je sugerirati postanak znatno šire državne cjeline, približno između Neretve i Drima te Jadrana i rijeke Tare, a time i etničke formacije.

Razvoj događaja ipak je otišao drugim smjerom. Dukljanska država od polovine 12. stoljeća sve više slabi te na njegovu kraju u potpunosti potpada pod vladare susjedne, pravoslavne Srbije. Riječ je o vremenu kada crkveni raskol iz 1054. stječe svoju punu važnost. Uspostavom Latinskog Carstva 1204. sa sjedištem u Carigradu katoličko-pravoslavni odnosi postaju obilježeni izrazitim polaritetom. U tim uvjetima, nakon uspostave 
vlastite crkve 1219., srpska dinastija Nemanjića počinje provoditi masovnu pravoslavizaciju zahumsko-dukljanskog prostora s ciljem utvrđivanja njegove lojalnosti (Ćorović, 1995; Šufflay, 1925). Prevjeravanju je primarno bio izložen slavenski katolički živalj, koji je u to vrijeme u cijelom jadransko-dinarskom pojasu po vanjskim manifestacijama svog kršćanskog identiteta, znatno određenih ćirilometodskom tradicijom, uvelike bio blizak susjednim pravoslavcima. Primorska, tada još uvijek u znatnoj mjeri romanska komunalna središta na tlu današnje Crne Gore, tj. Kotor, Budva, Bar i Ulcinj, te njima pripadajući slavenski živalj, jednako kao i albanska populacija uz rijeku Bojanu te u Malesiji ostavljeni su u katolicizmu.

Slabljenjem srpske države, od polovine 14. stoljeća, primorske komune postupno se povezuju sa zapadnim državama i u konačnici s Mletačkom Republikom. Istodobno, na dijelu današnjega crnogorskog teritorija nastanjenim pravoslavnim življem oblikuje se nova državna stvarnost u obliku Zete dinastije Balšića te poslije dinastije Crnojevića, koja pod osmanskim pritiscima državno središte locira u geopolitički najobranjivijim krajevima u podlovćenskoj Crnoj Gori. Za razliku od dijela mletačkih primorskih posjeda, prostori današnje Crne Gore do kraja 15. stoljeća naći će se pod osmanskom vlašću. No u njezinu podlovćenskom dijelu, pa i na temelju određene autonomije zadržane iz razdoblja Crnojevića, postupno će se razviti snažan protuosmanski otpor koji će dovesti do oblikovanja crnogorske države.

Iako je putem pravoslavlja, prožetog srpskim dinastičkim kultom, crnogorski živalj donekle ostajao u identitetnoj sferi protonacionalnog srpstva, posebnošću razvoja stjecao je i vlastitu etničku samosvijest (Dubak, 2011). Pritom se proces njezine artikulacije $u$ nacionalnu u znatnoj mjeri usporavao i slabio srpskim nacionalno-državotvornim djelovanjem, posebice nakon što je Srbija apsorbirala Crnu Goru 1918., a nedugo potom i njezinu autokefalnu crkvu inkorporirala u tada uspostavljenu Srpsku pravoslavnu crkvu (SPC). Ta postignuća srpske politike donekle su poništena 1943./1945. uspostavom Narodne (Socijalističke) Republike Crne Gore u sklopu federativne Jugoslavije i priznanjem crnogorske nacije, s tim da je nova vlast, izbjegavajući dodatno konfrontiranje s promotorima srpskih gledišta na Crnu Goru, podupirala stav prema kojem je crnogorska nacija srpskoga etničkog porijekla te dopustila (što nije bio slučaj s Makedonijom) da SPC ostane institucionalnim okvirom pravoslavlja u Crnoj Gori (Marković, 1974; Prekić, 2019). Na taj način stečenim te zadržanim 
organizacijskim monopolom nad crnogorskim pravoslavljem SPC je uspio trajno, pa i u uvjetima postojanja obnovljene crnogorske države, ostati glavnim i relativno uspješnim instrumentom opstrukcije crnogorske nacionalne emancipacije i rasadnikom srpske nacionalno-državotvorne ideje među crnogorskim pravoslavnim življem.

Slavenska katolička populacija na tlu današnje Crne Gore imala je drugačiji politički razvoj. Vezivanjem uz Zapad te poslije uz Veneciju bila je upućena k istojezičnim katolicima, prvenstveno u Mletačkoj Republici. Istodobno, u to doba ukupnu slaveno-katoličku populaciju snažno povezuju protuosmanski senzibilitet i angažman, čime se stvaraju pretpostavke za daljnju političku profilaciju te narodnosne cjeline. Kako je u njezinim okvirima najveću političku važnost zadržala Hrvatska, tijekom nacionalnoformativnih procesa ta se narodnosna cjelina postupno oblikuje u hrvatsku naciju (Pasinović, 2005). Pritom je slaveno-katolički živalj na tlu današnje Crne Gore, koji je u Boki Kotorskoj i Budvi od 1816./1817., a u Spiču od 1878. dijelom habsburške, većinski hrvatske i katoličke Kraljevine Dalmacije, bio sastavnim sudionikom procesa koji od polovine 19. stoljeća vode hrvatskoj nacionalnoj konstituciji (Ivković, 1991/1992).

Nastankom Kraljevine Srba, Hrvata i Slovenaca (dalje: Kraljevina SHS) 1918., preimenovane 1929. u Kraljevinu Jugoslaviju, iznova se izmijenio tijek povijesti. Ta tvorevina nastaje kao pokušaj amortizacije dubokih protuslovlja između hrvatske i srpske nacionalne ideologije. Korijen je njihova nastanka u 16. stoljeću, tijekom kojeg Osmanlije pustoše središnje hrvatske zemlje te ih po osvojenju masovno nastanjuju slaveno-pravoslavnim življem (Čubrilović, 1959), do te mjere da je pravoslavno stanovništvo koloniziranih krajeva steklo potencijal da po svom oblikovanju u dio srpske nacije istakne državotvorne zahtjeve ne samo na te krajeve već i na sve one etnički nesrpske teritorije koji su stajali na putu nastanaka velike srpske države. S druge strane, težnja Hrvata bila je usmjerena na regeneraciju hrvatske državne vlasti na tim prostorima.

Tijekom prve i druge Jugoslavije na različite se načine pokušavalo neutralizirati tenzije koje su proizlazile iz različitih nacionalno-državotvornih projekcija, i to ne samo one na razini hrvatsko-srpskih već i drugih nacionalnih relacija (hrvatsko-bošnjačko-srpskih, srpsko-crnogorskih, srpsko-albanskih, srpsko-makedonskih itd.). No u tome se tek donekle uspijevalo, i to ponajprije na manifestacijskoj razini. Ne samo da su se te tenzije održavale već su uz odgovarajuće uvjete i sačuvale sposobnost naglog aktiviranja, 
koju su posebno snažno očitovale za Drugoga svjetskog rata i prilikom raspada socijalističke Jugoslavije. U tim su se razdobljima prikupljala dodatna, negativna iskustva u kontekstu ovdašnjih nacionalnih odnosa i međusobnih doživljaja.

Na tlu današnje Crne Gore (slika 1), preciznije u njezinu primorju, Hrvati su tradicionalno, još prije suvremenih migracija, bili manjinsko stanovništvo. U istočnoj Boki, nekoć i u Budvi, zatim u istočnom Spiču i susjednom naselju Zupci pored Bara bili su većina, no posrijedi su bile enklave koje su graničile s brojnijim, pravoslavnim življem, odnosno u slučaju Bara i muslimanskim. Svejedno, do 1918. najvećim su dijelom živjeli, uvjetno rečeno, pod katoličkom vlašću te u tvorevini koja je imala njihove nacionalne značajke, tj. u Kraljevini Dalmaciji. Nakon te godine ne samo da se nalaze u državi obilježenoj srpskom prevlašću već su i u vlastitoj sredini, kao manjina, izloženi snažnom srpskom utjecaju. Od 1945. prvenstveno ih politički određuje pripadnost Crnoj Gori, u kojoj, međutim, još uvijek nije iskristalizirana prevladavajuća identitetna odrednica među pravoslavnim življem. Pritom ne samo da srpska identifikacija zadržava snažno uporište već se nerijetko i očituje u izrazito radikalnoj formi (Jovanović, 2016). U međuvremenu, od šezdesetih godina Hrvati su postali uočljivom manjinom i u glavnini naselja u kojima su nekoć bili jedinim ili prevladavajućim stanovništvom.

Drugim riječima, Hrvati su u Crnoj Gori od 1918. dijelom društvene atmosfere u kojoj, s obzirom na taložene tenzije, iskustva i predodžbe, očitovanje hrvatskog identiteta može predstavljati teret koji nisu svi spremni ili sposobni nositi. Osim toga od 1945. pa gotovo do osamostaljenja Crne Gore 2006. nije bilo uvjeta da se u sredini u kojoj žive institucionalno artikuliraju nacionalnoidentitetni poticaji iz Hrvatske. Sukladno tome, otkada popisi stanovništva uključuju nacionalnu odrednicu, tj. od 1948., u Crnoj Gori moguće je očitovati hrvatsku nacionalnu pripadnost, ali u uvjetima u kojima znatan ili danas već prevladavajući dio slaveno-katoličke populacije izbjegava to učiniti. 
Slika 1. Karta Crne Gore i crnogorskih općina (2011.)

Figue 1. Map of Montenegro and its' municipalities (2011)

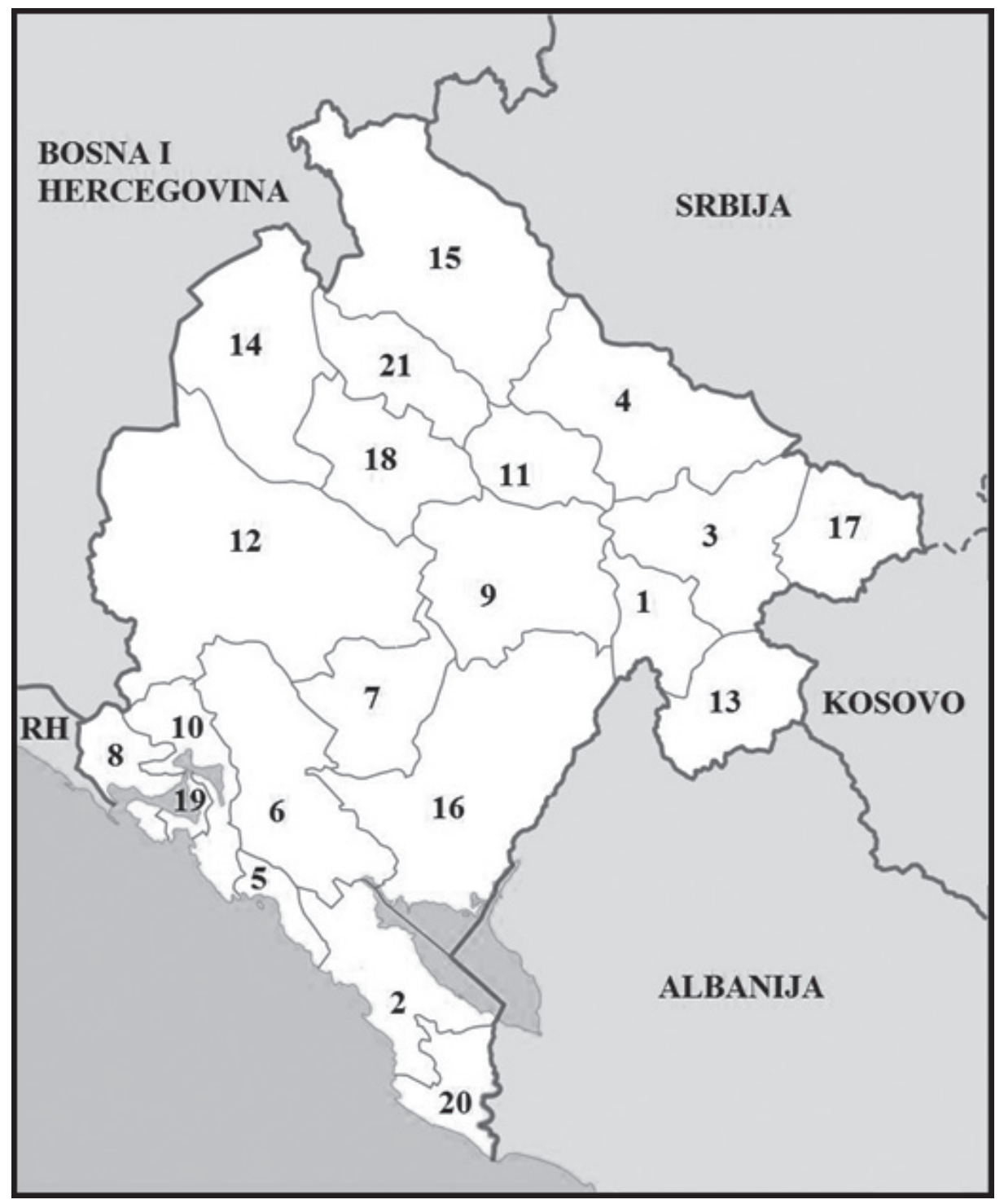

Općine Crne Gore (2011. godine): 1. Andrijevica; 2. Bar; 3. Berane; 4. Bijelo Polje; 5. Budva; 6. Cetinje; 7. Danilovgrad; 8. Herceg Novi; 9. Kolašin; 10. Kotor; 11. Mojkovac; 12. Nikšić, 13. Plav; 14. Plužine; 15. Pljevlja; 16. Podgorica; 17. Rožaje; 18. Šavnik; 19. Tivat; 20. Ulcinj; 21. Žabljak.

Kartu priredio i označio autor prema predlošku dostupnom na: https://en.wikipedia. org/wiki/Kotor (20. 05. 2021.). 


\section{BROJ HRVATA U CRNOJ GORI U POPISIMA 1948. - 2011.}

Suvremeni popisi na tlu današnje Crne Gore počeli su se provoditi polovinom 19. stoljeća upravo u kotaru Kotor, tj. onom njezinu dijelu koji je nekoć pripadao austrijskoj Kraljevini Dalmaciji (Crkvenčić i Schaller, 2005). Nisu uključivali pitanja o etničkoj pripadnosti, već o vjerskoj te od 1880. i jezičnoj. Tek od 1900. iz popisane mase stanovništva moguće je izuzeti relativno brojne vojnike kako bi se odgovarajućim kombinacijama stekao uvid u etnički sastav svih naselja u Dalmaciji, pa tako i u Boki Kotorskoj. Pritom se tek uvjetno analiziranu populaciju može razvrstati po pojedinim nacijama, i to ne samo zato što popis za takvo što ne pruža opravdanje već i stoga što do tada nacionalnoformativni procesi nisu u potpunosti okončani kako na promatranom tako i na znatno širem prostoru. U svakom slučaju 1900. je u kotaru Kotor živjelo približno 9565 ili 28\% Hrvata, odnosno osoba za koje je bilo gotovo izvjesno da bi u tadašnjim političkim uvjetima mogle biti integrirane u okvire nacionalnog hrvatstva (Mrduljaš, 2019), od čega oko 8332 ili 38,8\% od ukupne populacije u užoj Boki Kotorskoj (bez Krivošija i Grblja), koja tada ima tek 21.473 stanovnika, 308 u Budvi i 827 u Spiču. U Baru i njegovoj užoj okolici približno istodobno, tj. 1897., moglo je biti maksimalno 1265 Hrvata. $^{2}$

Prvi popis koji je istovremeno obuhvatio stanovništvo kotara Kotor kao i ono nastanjeno na ostatku teritorija današnje Crne Gore proveden je 1921. Ni u njemu nije evidentirana etnička pripadnost, već vjerska i jezična te se do broja Hrvata može doći samo posredno. Tada je na tlu današnje Crne Gore obitavalo oko 313.432 stanovnika, među kojima 238.334 ili $76 \%$ pravoslavaca, 55.802 ili 17,8\% muslimana, 19.146 ili 6,1\% katolika te 150 pripadnika drugih vjera. Među katolicima je približno bilo između 11.380 i 12.145 Hrvata (tablica 1). Do točnog iznosa vrlo je teško doći jer su u pojedinim sredinama, posebno onima u zaleđu, osim Hrvata katolika obitavali i Bošnjaci muslimani te Albanci muslimani i katolici, što otežava uvid u točan broj pripadnika svake od tih etnovjerskih skupina. No sigurno je da je već $\mathrm{u}$ to vrijeme osim nekih 10.560 - 11.000 Hrvata nastanjenih između Herceg Novog i Ulcinja, u crnogorskom zaleđu, ponajviše u Cetinju, Nikšiću, Podgorici, Pljevljima obitavalo 820 do 1150 Hrvata doseljenih u prethodnim razdobljima ili nakon uspostave Kraljevine SHS. Sveukupno, udio hrvatske populacije u stanovništvu nastanjenom na prostoru današnje Crne Gore 1921. bio je između 3,6\% i 3,9\%.

2 U Baru i susjednim naseljima živjelo je 675, a u mjestu Zupci, pored Spiča, 590 katolika, među kojima je, prvenstveno u samom Baru, vjerojatno bilo i Albanaca katolika (Rastoder, 1991). 
Tablica 1. Broj Hrvata na prostoru današnje Crne Gore prema popisu stanovništva iz 1921.

Table 1. The number of Croats in the area of today's Montenegro according to the 1921 census

\begin{tabular}{|c|c|c|c|c|c|c|}
\hline & Adm. j. ${ }^{*}$ & Dio p. c. & Naz. adm. j. & Ukup. st. 21. & H.-min. & H.-maks. \\
\hline 1 & Kotar & Dal. & Kotor & 35.305 & 9789 & 9883 \\
\hline 2 & Općina & $\mathrm{BiH}$ & Kruševica & 1084 & 6 & 6 \\
\hline 3 & Općina & $\mathrm{BiH}$ & Sutorina & 1007 & 11 & 11 \\
\hline 4 & Okrug & CG & Andrijevica & 24.624 & 10 & 12 \\
\hline 5 & Okrug & CG & Bar & 28.638 & 754 & 1098 \\
\hline 6 & Okrug & CG & Kolašin & 14.899 & 17 & 24 \\
\hline 7 & Okrug & CG & Nikšić & 50.516 & 225 & 266 \\
\hline 8 & Okrug & CG & Podgorica & 48.651 & 172 & 292 \\
\hline 9 & Okrug & CG & Cetinje & 31.899 & 209 & 335 \\
\hline 10 & Okrug & JS & Berane & 23.864 & 50 & 71 \\
\hline 11 & Okrug & JS & Bijelo Polje & 26.147 & 15 & 19 \\
\hline \multirow[t]{2}{*}{12} & Okrug & JS & Pljevlja & 26.798 & 122 & 128 \\
\hline & & & & 313.432 & 11.380 & 12.145 \\
\hline
\end{tabular}

* Objašnjenje kratica: »adm. j.« - administrativna jedinica; »dio p. c.« - dio prostorne cjeline u kojoj se nalazila pojedina administrativna jedinica tijekom popisa (»Dal.« - Dalmacija; »BiH« - Bosna i Hercegovina; »CG« - Crna Gora; »JS« - južna Srbija ); »naz. adm. j.« - naziv administrativne jedinice; »ukup. st. 21.« - ukupno stanovništvo pojedine administrativne jedinice 1921. godine; »H.min.« - minimalni broj Hrvata u pojedinoj administrativnoj jedinici; »H.-maks.« - maksimalni broj Hrvata u pojedinoj administrativnoj jedinici. Do iznosa u stupcu »H.-min.« došli smo tako da smo od ukupnog broja rimokatolika, grkokatolika, evangelika i judaista oduzeli govornike slovenskog, češkog/slovačkog, poljskog, mađarskog, njemačkog, talijanskog, francuskog i engleskog jezika uz pretpostavku da su tim izuzimanjem, osim govornika navedenih jezičnih grupacija, iz dobivenih iznosa izuzeti i svi nekatolici. Ujedno je iz dobivenih iznosa odbijen i određeni dio Albanaca za koje se nije mogla utvrditi vjerska pripadnost (katolici ili muslimani) te su uvršteni među katolike. U stupcu »H.-maks.« taj isti dio Albanaca u potpunosti je uvršten među muslimane, čime su dobiveni maksimalni iznosi Hrvata po administrativnim jedinicama.

Izvori: Definitivni rezultati popisa stanovništva od 31. januara 1921. god., Sarajevo, Kraljevina Jugoslavija, Opšta državna statistika, 1932: 86-87, 106-107, 122-129, 190-191, 248-249.

Prema prvom popisu provedenom u socijalističkoj Jugoslaviji, onom iz 1948., koji ujedno prvi registrira nacionalnu pripadnost, u Crnoj Gori bilo je svega 6808 Hrvata, od čega u Boki Kotorskoj 5958 (Hercegnovski i Kotorski srez), a u Baru i okolici tek 95. Na idućem popisu provedenom 1953. broj Hrvata uvećan je na 9814, pri čemu je u Boki iznosio 8182 (Bokokotorski srez), a Baru 399 (tablica 2). Dakle u pet godina porastao je za 3006 ili 44,15\%, od čega u Boki i Baru za 2528. Do uvećanja nije došlo zbog 
prirodnog prirasta ili useljavanja, već prvenstveno stoga što se u popisu 1948., sukladno ponuđenim obrascima izjašnjavanja, veliki dio naknadno iskazanih Hrvata očitovao Crnogorcima. Ipak, 1953. radilo se o djelomičnom povratku iz crnogorstva $u$ hrvatstvo jer se i te godine znatan dio autohtone slavenske katoličke populacije izjasnio Crnogorcima, ponajviše u Baru i okolici, gdje će unutar te populacije taj tip izjašnjavanja trajno zadržati prevagu, ne samo zato što je dio te populacije između 1878. i 1918. bio dijelom crnogorske države već i stoga što je riječ o donekle izoliranoj, malobrojnoj enklavi koja je unatoč izrazitoj povijesnoj važnosti ostala izvan matičnoga hrvatskog vidokruga, za razliku od primjerice Hrvata Boke Kotorske.

Tablica 2. Broj Hrvata u srezovima i gradovima Crne Gore prema popisima iz 1948. i 1953.

Table 2. Number of Croats in counties and cities of Montenegro according to the 1948 and 1953 censuses

\begin{tabular}{lrlr}
\hline Srez/Grad & 1948. & Srez/Grad & 1953. \\
\hline Barski & 95 & Barski & 399 \\
\hline Beranski & 21 & Beranski & 51 \\
\hline Andrijevički & 19 & & 48 \\
\hline Bijelopoljski & 13 & Bijelopoljski & 115 \\
\hline Cetinjski & 12 & Cetinjski & 5 \\
\hline Cetinje (grad) & 149 & & 8182 \\
\hline Durmitorski & 9 & Durmitorski & 34 \\
\hline Kotorski & 4622 & Bokokotorski & 386 \\
\hline Hercegnovski & 1336 & & 97 \\
\hline Kolašinski & 29 & Kolašinski & \\
\hline Nikšićki & 230 & Nikšićki & 99 \\
\hline Grad Nikšić & 67 & & 398 \\
\hline Pljevaljski & 2 & Pljevaljski & \\
\hline Pljevlja (grad) & 23 & & 9814 \\
\hline Podgorica & 7 & Podgorički & \\
\hline Podg. (grad) & 133 & Podg. (grad) & \\
\hline Danilovgradski & 41 & & \\
\hline & 6808 & & \\
\hline & & & \\
\hline
\end{tabular}

Izvori: Stalno stanovništvo po narodnosti po popisu od 15. marta 1948. godine, Beograd, 1954; Ukupno stanovništvo po narodnosti - popis 1953., Beograd, Republički zavod za statistiku. 
U popisima do 1971. jugoslavenska odrednica, u onoj mjeri u kojoj se upotrebljavala, prije svega se smatrala odrednicom unutar koje se registrira slaveno-muslimanska zajednica s obzirom na to da je tek polovinom šezdesetih godina prihvaćeno da je riječ o posebnoj naciji kojoj je određen i naziv, Muslimani. Nakon toga se slaveno-muslimanska populacija masovno počinje izjašnjavati Muslimanima, te jugoslavenska odrednica stječe drugačiji karakter: na određeni način postaje otvorenom za pripadnike svih jugoslavenskih naroda i manjinskih grupacija koji se žele izjasniti Jugoslavenima ili takvim izjašnjavanjem pokušavaju izbjeći mogućnost očitovanja autentične nacionalne pripadnosti. Sukladno tome, 1971. znatan dio crnogorskih Hrvata počinje se izjašnjavati Jugoslavenima (Mirić, 2000). Pad broja Hrvata uzrokovan takvim izjašnjavanjem bio je izrazito uočljiv. Primjerice, 1961. u općini Kotor živjelo je 3483 Hrvata, a deset godina poslije 2612, pri čemu je u istoj općini broj Jugoslavena iznosio 2171. Naknadno će doći do svojevrsnog zbjega crnogorskih Hrvata među Jugoslavene. Tako, dok je u Crnoj Gori 1961. živjelo 10.664 izjašnjenih Hrvata, na popisu iz 1991. njihov se broj sveo tek na 6244 (tablica 3).

Tablica 3. Broj Hrvata (H.), Jugoslavena (J.) i nacionalno neizjašnjenih (N.) po općinama Crne Gore 1961., 1971., 1981., 1991., 2003. i 2011.

Table 3. Number of Croats (H.), Yugoslavs (J.) and nationally undeclared (N.) by municipalities of Montenegro in 1961, 1971, 1981, 1991, 2003 and 2011

\begin{tabular}{|c|c|c|c|c|c|c|c|c|c|c|c|c|c|}
\hline & \multirow{2}{*}{$\begin{array}{c}1961 . \\
\mathrm{H} .\end{array}$} & \multicolumn{2}{|c|}{1971.} & \multicolumn{2}{|c|}{1981.} & \multicolumn{2}{|c|}{1991.} & \multicolumn{3}{|c|}{2003.} & \multicolumn{3}{|c|}{2011.} \\
\hline & & H. & $\mathrm{J}$. & H. & $\mathrm{J}$. & $\mathrm{H}$. & J. & H. & J. & N. & $\mathrm{H}$. & J. & N. \\
\hline Bar* & 266 & 273 & 955 & 231 & 3054 & 192 & 2739 & 259 & 163 & 1584 & 254 & 105 & 2097 \\
\hline Berane & 94 & 85 & 467 & 86 & 1099 & 44 & 706 & 46 & 72 & 1188 & 42 & 27 & 1250 \\
\hline Andrijevica & & & & & & 2 & 71 & 2 & 3 & 216 & 2 & 5 & 195 \\
\hline Bijelo Polje & 38 & 67 & 293 & 39 & 1087 & 55 & 326 & 45 & 24 & 847 & 41 & 27 & 952 \\
\hline Budva & 185 & 136 & 285 & 121 & 1272 & 142 & 1011 & 178 & 117 & 1116 & 167 & 74 & 1150 \\
\hline Cetinje & 109 & 60 & 149 & 58 & 249 & 47 & 328 & 49 & 27 & 277 & 42 & 17 & 457 \\
\hline Danilovgrad & 89 & 39 & 73 & 53 & 315 & 37 & 262 & 46 & 29 & 467 & 55 & 30 & 1034 \\
\hline Herceg Novi & 1544 & 1195 & 2553 & 702 & 8006 & 636 & 5243 & 798 & 270 & 2746 & 662 & 157 & 2908 \\
\hline Kolašin & 60 & 75 & 56 & 17 & 135 & 15 & 147 & 11 & 34 & 331 & 7 & 22 & 323 \\
\hline Kotor & 3483 & 2612 & 2171 & 1644 & 5271 & 1620 & 4113 & 1762 & 168 & 2165 & 1553 & 93 & 1946 \\
\hline Mojkovac & 41 & 27 & 31 & 22 & 102 & 8 & 124 & 4 & 20 & 322 & 2 & 20 & 330 \\
\hline Nikšić & 413 & 272 & 421 & 201 & 1786 & 117 & 1332 & 132 & 267 & 5214 & 149 & 161 & 4846 \\
\hline Plav & 19 & 37 & 43 & 20 & 397 & 3 & 100 & 4 & 3 & 39 & 5 & 2 & 107 \\
\hline
\end{tabular}




\begin{tabular}{lrrrrrrrrrrrrr}
\hline & 1961. & \multicolumn{1}{c}{1971.} & \multicolumn{1}{c}{1981.} & \multicolumn{2}{c}{ 1991. } & \multicolumn{2}{c}{ 2003. } & \multicolumn{2}{c}{2011.} \\
\hline & H. & H. & \multicolumn{1}{c}{ J. } & H. & J. & H. & J. & H. & J. & N. & H. & J. & N. \\
\hline Plužine & 15 & 23 & 13 & 9 & 27 & 5 & 30 & 1 & 8 & 263 & 2 & 1 & 201 \\
\hline Pljevlja & 83 & 43 & 355 & 54 & 1384 & 7 & 818 & 16 & 49 & 1437 & 16 & 20 & 1448 \\
\hline Podgorica & 736 & 788 & 1846 & 686 & 5192 & 608 & 5047 & 709 & 495 & 6978 & 664 & 310 & 8892 \\
\hline Rožaje & 2 & 6 & 50 & 8 & 144 & 8 & 139 & 4 & & 53 & 6 & & 72 \\
\hline Šavnik & 5 & 4 & 17 & 15 & 36 & 6 & 32 & 3 & 16 & 98 & 1 & 3 & 47 \\
\hline Tivat & 3423 & 3375 & 634 & 2876 & 2384 & 2640 & 2347 & 2663 & 71 & 1117 & 2304 & 61 & 1275 \\
\hline Ulcinj & 55 & 70 & 522 & 61 & 1150 & 51 & 1191 & 77 & 22 & 186 & 45 & 14 & 425 \\
\hline Žabljak & 4 & 5 & 9 & 1 & 56 & 1 & 53 & 2 & 2 & 262 & 2 & 5 & 215 \\
\hline & & & & & & & & & & & & \\
\hline
\end{tabular}

* Napomene u vezi s nazivima i prostornim okvirom crnogorskih općina: 1) grad Berane je između 1949. i 1992. nazivan Ivangradom kao i općina čijim je središtem; 2) od južnog dijela općine Ivangrad/Berane oformljena je 1990. općina Andrijevica; 3) između 1946. i 1992. Podgorica se nazivala Titogradom kao i općina čijim je središtem; 4) grad Rožaje, a time i općina čijim je središtem imenovan je do popisa iz 2003. kao Rožaj. U tablici 3 i u ostatku rada isključivo se koristimo nazivima Berane, Podgorica i Rožaje.

Izvori: Popis stanovništva, domaćinstava i stanova u 1961. godini. Nacionalni sastav stanovništva FNR Jugoslavije (podaci po naseljima i opštinama), knjiga III, Beograd, Savezni zavod za statistiku, 1994; Popis stanovništva i stanova 1971. Stanovništvo - etnička, prosvetna i ekonomska obeležja stanovništva i domaćinstava prema broju članova (rezultati po opštinama), knjiga VI, Beograd, Savezni zavod za statistiku, 1994; Nacionalni sastav stanovništva SFR Jugoslavije 1981. (podaci po naseljima i opštinama), knjiga I, Beograd, Savezni zavod za statistiku, 1991; Stanovništoo prema nacionalnoj pripadnosti 1991., Beograd, Republički zavod za statistiku; Popis stanovništva, domaćinstava i stanova u 2003. Stanovništvo: nacionalna ili etnička pripadnost - Podaci po naseljima i opštinama, Podgorica, Zavod za statistiku, 2004; Popis stanovništva i stanova 1971. Stanovništvo - etnička, prosvetna i ekonomska obeležja stanovništva i domaćinstava prema broju članova (rezultati po opštinama), knjiga VI, Beograd, Savezni zavod za statistiku, 1994.

Poslije raspada socijalističke Jugoslavije, u prilikama kada sve izvjesnijim postaje i raspad Savezne Republike Jugoslavije, koju su konstituirale Srbija i Crna Gora, odrednica »Jugoslaveni« zadržava se i u crnogorskom popisu iz 2003., pa i onom iz 2011., provedenom nakon 2006. i disolucije Državne zajednice Srbije i Crne Gore, no nužno gubi na važnosti (Mišetić, 2018). U popisima iz 2003. i 2011. očituje se izrazito smanjenje broja osoba koje su se prethodno izjašnjavale Jugoslavenima, pri čemu, konkretno u hrvatskom slučaju, ne dolazi do njihova povratka u okvire nacionalnog hrvatstva. Umjesto toga većina takvih osoba na spomenutim se popisima uopće nacionalno ne izjašnjava (»neizjašnjeni«), iskazuje regionalnu umjesto nacionalne pripadnosti (npr. Bokelji), očituje se nacionalnim Crnogorcima itd. 
Crnogorski popisi iz 2003. i 2011. razlikuju se od prijašnjih po tome što kod ta dva popisa nisu registrirani crnogorski državljani koji su duže od godine dana bili na privremenom radu u inozemstvu, odnosno popisivani su strani državljani koji su duže od godinu dana boravili u Crnoj Gori. Stoga pokazatelji između prijašnjih popisa te onih provedenih 2003. i 2011. nisu posve usporedivi. Svejedno, u odnosu na 1991. broj Hrvata je 2003. porastao te je iznosio 6811. No već 2011. pada na 6021, tj. na svoju najnižu dosadašnju razinu (tablica 3), zapravo i na manju od iskazane u popisu ako se uzme $u$ obzir da je među Hrvate 2011. upisano i 90 pravoslavaca (tablica 4). Oni su se u hrvatskome nacionalnom okviru vjerojatno našli zbog obiteljskih prilika, tako što su u pojedinim slučajevima unutar etnički i vjerski heterogenih obitelji njihovi članovi registrirani kao dio jedne nacionalne skupine. Može se pretpostaviti da je o istoj pojavi riječ i u slučaju 112 Srba ili tri Muslimana katoličke vjere.

Tablica 4. Izjašnjavanje Hrvata u Crnoj Gori o vjeri u popisu iz 2011.

Table 4. Religious affiliation of Croats in Montenegro in the 2011 census

\begin{tabular}{|c|c|c|c|c|c|c|c|c|c|c|c|c|c|}
\hline Općina & Ukup.* & Ad. & Ag. & At. & B. & Kršć. & M. & Js. & Kat. & Ne. & Ost. & Prav. & P. \\
\hline Andrijevica & 2 & & & & & & & & 2 & & & & \\
\hline Bar & 254 & & & 10 & & 1 & & & 216 & 12 & 1 & 10 & 4 \\
\hline Berane & 42 & & & 3 & & & & & 30 & 5 & 1 & 3 & \\
\hline Bijelo Polje & 41 & & & & & & & & 38 & 1 & 1 & 1 & \\
\hline Budva & 167 & & 1 & 3 & & & & & 156 & 2 & & 5 & \\
\hline Cetinje & 42 & & & 2 & & 1 & & & 34 & 2 & 1 & 2 & \\
\hline Danilovgrad & 55 & & & 3 & & 4 & & & 45 & 1 & & 2 & \\
\hline Herceg Novi & 662 & & 4 & 57 & & 3 & & & 557 & 29 & & 12 & \\
\hline Kolašin & 7 & & & & & & & & 7 & & & & \\
\hline Kotor & 1553 & 1 & 1 & 24 & & 4 & & & 1507 & 8 & 3 & 5 & \\
\hline Mojkovac & 2 & & & & & & & & 2 & & & & \\
\hline Nikšić & 149 & & & 7 & & 3 & & & 125 & 5 & 2 & 7 & \\
\hline Plav & 5 & & & & & & & & 5 & & & & \\
\hline Plužine & 2 & & & & & & & & 2 & & & & \\
\hline Pljevlja & 16 & & & & & & & & 13 & & 1 & 2 & \\
\hline Podgorica & 664 & 1 & 4 & 55 & & 9 & & 2 & 524 & 24 & 7 & 36 & 2 \\
\hline Rožaje & 6 & & & & & & 1 & & 5 & & & & \\
\hline Šavnik & 1 & & & & & & & & 1 & & & & \\
\hline Tivat & 2304 & & 5 & 40 & & 7 & 2 & 1 & 2221 & 20 & 5 & 2 & 1 \\
\hline
\end{tabular}




\begin{tabular}{|c|c|c|c|c|c|c|c|c|c|c|c|c|c|}
\hline Općina & Ukup. ${ }^{*}$ & Ad. & Ag. & At. & B. & Kršćc. & M. & Js. & Kat. & Ne. & Ost. & Prav. & P. \\
\hline Ulcinj & 45 & & & 3 & 1 & 1 & & & 35 & 1 & 1 & 3 & \\
\hline Žabljak & 2 & & & & & & & & 2 & & & & \\
\hline & 6021 & 2 & 15 & 207 & 1 & 33 & 3 & 3 & 5527 & 110 & 23 & 90 & 7 \\
\hline
\end{tabular}

* Objašnjenje kratica: »ukup.« - ukupno; »ad.« - adventisti; »ag.« - agnostici; »at.« - ateisti; »b.« - budisti; »kršć.« - neidentificirani kršćani; »m.« - muslimani; »js.« - Jehovini svjedoci; »kat.« katolici; »ne.« - vjerski neizjašnjeni; »ost.« - pripadnici ostalih vjera; »prav.« - pravoslavci; »p.« - protestanti.

Izvori: Tabela O2. Stanovništvo prema nacionalnoj odnosno etničkoj pripadnosti i vjeroispovijesti po opštinama, Popis stanovništva, domaćinstava i stanova u Crnoj Gori 2011. godine, Podgorica, MONSTAT - Uprava za statistiku.

Sve u svemu, otkada se u Crnoj Gori provode popisi koji uključuju nacionalnu pripadnost, broj izjašnjenih Hrvata je do 2011. gotovo prepolovljen. Bez pravoslavnih koji su upisani kao Hrvati njihov je broj te godine iznosio svega 5931, od čega 4500 u Boki Kotorskoj. U svakom slučaju, toliki je broj popisno utvrđenih Hrvata. No postavlja se pitanje koliko su u Crnoj Gori bili brojni preostali Slaveno-katolici, od kojih se najveći dio prethodno izjašnjavao Hrvatima ili pripadao porodicama unutar kojih je takvo izjašnjavanje bilo prisutno.

\section{BROJ SLAVENO-KATOLIČKE POPULACIJE U CRNOJ GORI KOJA SE U POPISU 2011. NIJE IZJASNILA HRVATIMA, ALI JE OČITOVALA PRIPADNOST KATOLICIZMU}

Zahvaljujući dostupnosti niza podataka koji se odnose na popis stanovništva Crne Gore 2011., moguće je, između ostaloga, registrirati kako su se ispitanici deklarirali nacionalno i po pitanju svog vjerskog identiteta, $i$ to na razini Crne Gore, njezinih općina i naselja, a zatim i na razini pojedinačnih nacionalnih grupacija. Sukladno tome do određene se mjere može utvrditi i broj onih ispitanika koji se nisu izjasnili Hrvatima, ali koji prema jeziku i vjeri pripadaju slaveno-katoličkoj cjelini. Riječ je o ispitanicima, odnosno članovima njihovih obitelji koji su u popisu naveli svoju pripadnost katolicizmu, ali su se u kontekstu nacionalnosti očitovali kao Crnogorci, Muslimani, Srbi ili kao pripadnici nacionalno nepostojećih, ali popisno prihvaćenih kategorija, tj. kao Bosanci, Jugoslaveni, Srbi-Crnogorci, nacionalno neizjašnjeni (neizjašnjeni) ili regionalno izjašnjeni. Pritom ne mora značiti da je ukupni broj osoba koje su se očitovale katolicima i pripadnicima spomenutih nacionalnih ili za popis konstruiranih grupacija tradicionalno pri- 
padao slaveno-katoličkoj cjelini. No i unutar samog nacionalnog hrvatstva inkorporiran je znatan dio pojedinaca koji po (daljnjem) porijeklu nisu ukorijenjeni na središnjem južnoslavenskom prostoru. Osim toga, ako uzmemo u obzir brojnost hrvatskog življa na teritoriju koji zauzima današnja Crna Gora početkom 20. stoljeća kao i u popisima 1953., 1961. i 1971., s visokom dozom sigurnosti možemo ustvrditi da daleko najveći dio tih osoba pripada slaveno-katoličkoj zajednici.

Kako se iz tablice 5 može vidjeti, zbroj te populacije iznosio je 6825, pri čemu su unutar nje Crnogorci katolici brojili 5667 ili 83\%. Dakle, 2011. broj Crnogoraca katolika bio je veći od broja Hrvata katolika u Crnoj Gori, koji je iznosio 5527. Mnogobrojnost Crnogoraca katolika unutar ukupne slavenokatoličke zajednice u Crnoj Gori zahtijeva osvrt. Naime, izjašnjavanje Slaveno-katolika Crnogorcima u popisima 1948. - 1991., odnosno u vremenu dok se crnogorstvo najčešće shvaćalo kao svojevrsna grana srpstva, zasigurno je moglo olakšati društvene pozicije, no ono jednostavno nije apsorbiralo presudne značajke njihova identiteta. O tome uz ostalo svjedoči i to da se u postojećim uvjetima slaveno-katoličko stanovništvo Crne Gore, unatoč kontinuiranoj izloženosti srpskoj propagandi, praktički u potpunosti izbjegava identificirati sa srpstvom.

Tablica 5. Katolici koji su se na crnogorskom popisu iz 2011. izjasnili kao Bosanci, Crnogorci, Jugoslaveni, Muslimani, Srbi, Srbi-Crnogorci, koji se nisu izjasnili o nacionalnosti (»neizjašnjeni«) ili su se izjasnili u regionalnom smislu

Table 5. Catholics who declared themselves as Bosnians, Montenegrins, Yugoslavs, Muslims, Serbs, Serb-Montenegrins on the Montenegrin census from 2011, who did not declare their nationality ("undeclared") or declared themselves in a regional sense

\begin{tabular}{|c|c|c|c|c|c|c|c|c|c|}
\hline Općina & Ukup.* & B. & CG. & $\mathrm{J}$. & M. & N. & R. & S. & S.-C. \\
\hline Andrijevica & 2 & & 2 & & & & & & \\
\hline Bar & 2676 & 3 & 2535 & 17 & & 83 & 9 & 28 & 1 \\
\hline Berane & 25 & 2 & 18 & & & 3 & & 2 & \\
\hline Bijelo Polje & 21 & & 18 & & & & & 3 & \\
\hline Budva & 125 & & 114 & 1 & & & 4 & 6 & \\
\hline Cetinje & 70 & 1 & 65 & & & 3 & 1 & & \\
\hline Danilovgrad & 51 & 2 & 43 & & & 3 & & 3 & \\
\hline Herceg Novi & 578 & 10 & 403 & 10 & & 69 & 62 & 24 & \\
\hline Kolašin & 12 & 1 & 8 & & & 1 & 2 & & \\
\hline
\end{tabular}




\begin{tabular}{|c|c|c|c|c|c|c|c|c|c|}
\hline Općina & Ukup.* & B. & CG. & $\mathrm{J}$. & M. & N. & R. & S. & S.-C. \\
\hline Kotor & 1012 & 1 & 768 & 20 & & 124 & 89 & 10 & \\
\hline Mojkovac & 4 & & 2 & & & & & 2 & \\
\hline Nikšić & 59 & 1 & 55 & & & 1 & & 2 & \\
\hline Plav & 5 & & & & & 1 & & 4 & \\
\hline
\end{tabular}

Plužine

\begin{tabular}{lrrrrrrrr}
\hline Pljevlja & 5 & & 3 & & & 1 & & 1 \\
\hline Podgorica & 1261 & 6 & 979 & 13 & 2 & 107 & 134 & 20 \\
\hline Rožaje & 4 & & 3 & & & & & 1
\end{tabular}

Šavnik

\begin{tabular}{lrrrrrrrr}
\hline Tivat & 496 & 1 & 341 & 7 & 1 & 81 & 60 & 5 \\
\hline Ulcinj & 417 & 1 & 309 & & & 92 & 15 & \\
\hline Žabljak & 2 & & 1 & & & & & 1
\end{tabular}

\begin{tabular}{lllllllll}
\hline 6825 & 29 & 5667 & 68 & 3 & 569 & 376 & 112 & 1 \\
\hline
\end{tabular}

* Objašnjenje kratica: »Ukup.« - ukupno; »B.«-Bosanci; »CG.« - Crnogorci; »J.« - Jugoslaveni; »M.«-Muslimani; »N.« - nacionalno neizjašnjeni; »R.« - regionalno izjašnjeni; »S.« - Srbi; »S.-C.« - Srbi-Crnogorci.

Izvori: Tabela O2. Stanovništvo prema nacionalnoj odnosno etničkoj pripadnosti i vjeroispovijesti po opštinama, Popis stanovništva, domaćinstava i stanova u Crnoj Gori 2011. godine, Podgorica, MONSTAT - Uprava za statistiku.

Od katoličke, nacionalno crnogorski izjašnjene populacije i nije se moglo očekivati da iskreno prihvati crnogorstvo koje podrazumijeva njezino srpsko porijeklo i poistovjećivanje sa srpskim identitetnim sadržajima. Štoviše, da sukladno tome prihvati i sve ono što bi se u suvremenome političkom kontekstu očekivalo od osoba srpskog porijekla, između ostaloga i gledišta koja unutar nacionalnog srpstva prevladavaju prema katolicizmu, Zapadu, Hrvatima i Hrvatskoj. No prilike se mijenjaju afirmacijom nacionalnog crnogorstva, isticanjem njegove samosvojnosti u odnosu na srpstvo, pa i davanjem izrazite važnosti dukljanskoj, katoličkoj dionici crnogorske povijesti (Peričić, 1991) te samim tim i blagonaklonim ili barem korektnim odnosom prema katolicizmu, Zapadu, Hrvatima i Hrvatskoj. Pritom je samosvojno crnogorstvo ne samo stjecalo značajke koje se dijelom preklapaju s identitetnim značajkama Slaveno-katolika već je zbog snažne izloženosti pritiscima od srpske nacionalno-državotvorne ideologije i akumuliralo iskustvo koje im nije nepoznato (Banac, 1988). Stoga za slaveno-katoličku populaciju crnogorstvo ima bitno drugačiju važnost od svih drugih oblika »nehrvatskoga« nacionalnog očitovanja. No da bi uistinu bilo stabilnom odrednicom 
(dijela) te populacije, trebalo bi pokazati održivost $u$ izvornome crnogorskom ambijentu te $\mathrm{u}$ većinski hrvatskim sredinama.

Od drugih »nehrvatskih « oblika nacionalnog izjašnjavanja Slaveno-katolici su se u znatnijoj mjeri očitovali kao nacionalno neizjašnjeni (569) i regionalno izjašnjeni (376), dok je izjašnjavanje Jugoslavenima (68) ili iz BiH doseljenim Bosancima (29) bilo periferno. Izjašnjavanje Srbima (112), SrbimaCrnogorcima (1) te Muslimanima (3) bilo je također limitirana dosega i u prvom bi se redu, kako je istaknuto, trebalo promatrati kroz prizmu etnički i vjerski heterogenih obitelji i izjašnjavanja unutar njih. U svakom slučaju, Hrvata (ne računajući pravoslavce koji su popisani kao Hrvati) 2011. zajedno sa ostalim Slaveno-katolicima bilo je 12.754 ili oko 2,1\% od ukupnog stanovništva Crne Gore.

Brojčani odnos u tradicionalnim sredinama u kojima su obitavali Hrvati (ne računajući pravoslavce koji su popisani kao Hrvati) i ostali Slaveno-katolici bio je sljedeći: u općinama Boke Kotorske (Herceg Novi, Kotor, Tivat) 4500 prema 2086, u Budvi 162 prema 125, Baru 244 prema 2676 i Ulcinju 42 prema 417. Takvih, nacionalno i vjerski izjašnjenih Slaveno-katolika (Hrvata, Crnogoraca itd.) bilo je, dakle, u crnogorskom primorju oko 10.252, dok ih je 2502 obitavalo u drugim dijelovima Crne Gore, ponajviše u Podgorici. Valja istaknuti da su Hrvati i ostali Slaveno-katolici kontinentalnog dijela Crne Gore velikim dijelom doseljenici ili potomci doseljenika iz Hrvatske, $\mathrm{BiH}$ i Srbije (Vojvodina) koji su se zbog posla ili obiteljskih razloga nastanili u Crnoj Gori uglavnom za trajanja obiju Jugoslavija. Tim je doseljavanjima donekle amortizirano iseljavanje Hrvata i ostalih Slaveno-katolika iz njihovih matičnih područja u Crnoj Gori, tj. iz Boke Kotorske, Budve te Bara i njegove okolice (Pasinović, 2005).

\section{BROJ SLAVENO-KATOLIČKE POPULACIJE U CRNOJ GORI KOJA SE U POPISU 2011. NIJE IZJASNILA HRVATIMA NITI JE OČITOVALA PRIPADNOST KATOLICIZMU}

Zbroj Hrvata (neračunajući pravoslavce koji su popisani kao Hrvati), Crnogoraca katolika i ostalih pripadnika slaveno-katoličke zajednice sasvim je sigurno nadilazio ovdje utvrđeni, približni iznos od 12.756, no u osnovi je nemoguće utvrditi u kojoj mjeri. U slučajevima gdje se pripadnici te jezičnovjerske cjeline nisu izjasnili Hrvatima ili gdje su očitovali pripadnost drugim nacijama ili grupacijama - Bosancima, Crnogorcima, Jugoslavenima, Muslimanima, nacionalno neizjašnjenima, regionalno izjašnjenima, Srbima 
i Srbima-Crnogorcima - ali ne i pripadnost katoličkoj vjeri, praktički im se u kontekstu popisa zameo trag. Izvjesno je da se najveći broj takvih pojedinaca nalazio među Bosancima, Crnogorcima, Jugoslavenima, nacionalno neizjašnjenima i regionalno izjašnjenima koji su se po pitanju vjere očitovali kao ateisti, agnostici, neidentificirani kršćani ili se uopće nisu očitovali (vjerski neizjašnjeni). Prema popisu iz 2011., u Crnoj Gori ukupno je bilo 25.758 ateista, agnostika, neidentificiranih kršćana ili vjerski neizjašnjenih osoba te su predstavljali 4,1\% njezine populacije. Pritom je 90\% njih (23.181) bilo unutar grupacije koju bi formirali Bosanci (32), Crnogorci (10.322), Jugoslaveni (305), nacionalno neizjašnjeni (12.402) i regionalno izjašnjeni (120) (tablica 6).

Tablica 6. Izjašnjavanje Bosanaca, Crnogoraca, Jugoslavena, neizjašnjenih i regionalno izjašnjenih o vjeri prema crnogorskom popisu iz 2011.

Table 6. Religious affiliation of Bosnians, Montenegrins, Yugoslavs, undeclared and regionally declared in Montenegro in the 2011 census

\begin{tabular}{lrrrrrrrrrrrrr}
\hline Nacija & Ukup. & Ad. & Ag. & At. & B. & Kršć. & M. & Js. & Kat. & Ne. & Ost. & Prav. & P. \\
\hline Bosanci & 427 & 1 & & 19 & & & 169 & & 30 & 13 & 4 & 191 & \\
\hline Crnogorci & 278.865 & 157 & 348 & 5876 & 53 & 875 & 12.758 & 72 & 5667 & 3223 & 3060 & 246.733 & 43 \\
\hline Jugoslaveni & 1154 & 1 & 5 & 223 & 4 & 25 & 30 & 1 & 68 & 52 & 26 & 719 & \\
\hline Neizjašnjeni & 30.170 & 17 & 15 & 283 & 8 & 81 & 887 & 30 & 580 & 12.023 & 227 & 16.018 & 1 \\
\hline Regionalno & 1202 & 3 & 8 & 66 & 2 & 21 & 26 & 1 & 376 & 25 & 22 & 651 & 1 \\
\hline & & 179 & 376 & 6467 & 67 & 1002 & 13.870 & 104 & 6721 & 15.336 & 3339 & 264.312 & 45 \\
\hline
\end{tabular}

* Objašnjenje kratica: »ukup.« - ukupno; »kat.« - katolici; »prav.« - pravoslavci; »mus.« - muslimani; »ost.« - pripadnici ostalih vjera; »ne.« - zbroj agnostika, ateista, neidentificiranih kršćana i vjerski neizjašnjenih po općinama Crne Gore; »ne.-1 « zbroj agnostika, ateista, neidentificiranih kršćana i vjerski neizjašnjenih koji su se nacionalno izjasnili kao Bosanci, Crnogorci, Jugoslaveni, koji se nisu nacionalno izjasnili ili koji su se regionalno izjasnili; »ne.-2« - zbroj agnostika, ateista, neidentificiranih kršćana i vjerski neizjašnjenih kada se izuzmu oni među njima koji su se izjasnili kao Bosanci, Crnogorci, Jugoslaveni, nacionalno neizjašnjeni ili regionalno izjašnjeni.

Izvori: Tabela CG5. Stanovništvo prema nacionalnoj odnosno etničkoj pripadnosti i vjeroispovijesti, Popis stanovništva, domaćinstava i stanova u Crnoj Gori 2011. godine, Podgorica, MONSTAT-Uprava za statistiku.

Na temelju konstatacije da se upravo unutar iznosa od 23.181, koji je obuhvaćao 3,7\% od ukupnog stanovništva Crne Gore, nalazio najveći dio preostalih Slaveno-katolika vrlo je teško izvoditi daljnje zaključke o njihovoj brojnosti. No oni su donekle mogući prvenstveno u kontekstu Boke Kotorske. Kako se iz tablice 7 (oznaka »Ne.«) može vidjeti, udio ateista, agnostika, 
neidentificiranih kršćana ili vjerski neizjašnjenih osoba među svim nacijama i popisnim grupacijama razlikovao se od jedne do druge crnogorske općine. Bio je neznatan unutar pretežito bošnjačkih/muslimanskih i albanskih sredina, odnosno među Bošnjacima/Muslimanima i Albancima. Stoga bi se moglo ustvrditi da su se $u$ heterogenim, pravoslavno-muslimanskim općinama ponajprije tradicionalni pripadnici pravoslavne zajednice očitovali kao ateisti, agnostici, neidentificirani kršćani ili vjerski neizjašnjeni (općine Pljevlja, Bijelo Polje, Berane, Rožaje i Plav). U ruralnim sredinama, u kojima je pravoslavni živalj bio gotovo jedinom populacijom, taj je udio bio između 1,7\% i 3,3\% (općine Andrijevica, Kolašin, Mojkovac, Plužine, Šavnik i Žabljak). Unutar općina sa značajnim ili značajnijim gradskim centrima u koje se u većoj mjeri doseljavalo i nepravoslavno stanovništvo, Nikšić, Cetinje, Danilovgrad i Podgorica, taj je postotak bio između 4,1 i 4,9.

No u Boki Kotorskoj udio ateista, agnostika, neidentificiranih kršćana ili vjerski neizjašnjenih osoba među svim nacijama i popisnim grupacijama bio je daleko veći. U Herceg Novom takvih je osoba bilo 8,8\%, u općini Kotor $7,3 \%$ te $u$ općini Tivat $8,5 \%$. S obzirom na prikazane udjele ateista, agnostika, neidentificiranih kršćana ili vjerski neizjašnjenih osoba u »pravoslavnim« općinama i na činjenicu da se muslimanska/bošnjačka i albanska populacija periferno vjerski očitovala na taj način, držimo da se s pravom može pretpostaviti da je od 4853 bokeljskih ateista, agnostika, neidentificiranih kršćana ili vjerski neizjašnjenih osoba koje su se očitovale kao Bosanci, Crnogorci, Jugoslaveni, nacionalno neizjašnjeni i regionalno izjašnjeni znatan dio pripadao slaveno-katoličkoj zajednici.

Tablica 7. Izjašnjavanje o vjeri po općinama Crne Gore prema popisu iz 2011. Table 7. Religious affiliation in municipalities of Montenegro according to the 2011 census

\begin{tabular}{lrrrrrrrrrrrrrrr}
\hline Općina & Ukup. & Kat. & $\%$ & Prav. & $\%$ & Mus. & $\%$ & Ost. & $\%$ & Ne. & $\%$ & Ne.-1 & $\%$ & Ne.-2 & $\%$ \\
\hline Andrijevica & 5071 & 6 & 0,1 & 4909 & 96,8 & 8 & 0,2 & 61 & 1,2 & 87 & 1,7 & 78 & 1,5 & 9 & 0,2 \\
\hline Bar & 42.048 & 3043 & 7,2 & 24.452 & 58,2 & 12.671 & 30,1 & 232 & 0,6 & 1650 & 3,9 & 1463 & 3,5 & 187 & 0,4 \\
\hline Berane & 33.970 & 81 & 0,2 & 23.287 & 68,6 & 9502 & 28,0 & 393 & 1,2 & 707 & 2,1 & 635 & 1,9 & 72 & 0,2 \\
\hline Bijelo Polje & 46.051 & 79 & 0,2 & 24.662 & 53,6 & 19.640 & 42,6 & 1084 & 2,4 & 462 & 1,3 & 462 & 1,0 & 124 & 0,3 \\
\hline Budva & 19.218 & 432 & 2,2 & 16.947 & 88,2 & 654 & 3,4 & 176 & 0,9 & 1133 & 5,9 & 881 & 4,6 & 252 & 1,3 \\
\hline Cetinje & 16.657 & 153 & 0,9 & 15.349 & 92,1 & 127 & 0,8 & 285 & 1,7 & 743 & 4,4 & 657 & 3,9 & 86 & 0,5 \\
\hline Danilovgrad & 18.472 & 140 & 0,8 & 17.047 & 92,3 & 262 & 1,4 & 262 & 1,4 & 761 & 4,1 & 703 & 3,8 & 58 & 0,3 \\
\hline Herceg N. & 30.864 & 1267 & 4,1 & 26.012 & 84,3 & 622 & 2,0 & 231 & 0,7 & 2732 & 8,8 & 2382 & 7,7 & 350 & 1,1 \\
\hline Kolašin & 8380 & 28 & 0,3 & 7795 & 93,0 & 45 & 0,5 & 258 & 3,1 & 254 & 3 & 234 & 2,8 & 20 & 0,2 \\
\hline
\end{tabular}




\begin{tabular}{lrrrrrrrrrrrrrrrr}
\hline Općina & Ukup. & Kat. & $\%$ & Prav. & $\%$ & Mus. & $\%$ & Ost. & $\%$ & Ne. & $\%$ & Ne.-1 & $\%$ & Ne.-2 & $\%$ \\
\hline Kotor & 22.601 & 2658 & 11,8 & 17.634 & 78,0 & 375 & 1,7 & 294 & 1,3 & 1640 & 7,3 & 1483 & 6,6 & 157 & 0,7 \\
\hline Mojkovac & 8622 & 8 & 0,1 & 8250 & 95,7 & 25 & 0,3 & 88 & 1,0 & 251 & 2,9 & 240 & 2,8 & 11 & 0,1 \\
\hline Nikšić & 72.443 & 222 & 0,3 & 66.198 & 91,4 & 1732 & 2,4 & 847 & 1,2 & 3444 & 4,7 & 3273 & 4,5 & 171 & 0,2 \\
\hline Plav & 13.108 & 124 & 0,9 & 2815 & 21,5 & 10.046 & 76,6 & 44 & 0,3 & 79 & 0,6 & 68 & 0,5 & 11 & 0,1 \\
\hline Plužine & 3246 & 2 & 0,1 & 3152 & 97,1 & & 0,0 & 1 & 0,0 & 91 & 2,8 & 86 & 2,6 & 5 & 0,2 \\
\hline Pljevlja & 30.786 & 24 & 0,1 & 24.346 & 79,1 & 5039 & 16,4 & 453 & 1,5 & 924 & 3 & 842 & 2,7 & 82 & 0,3 \\
\hline Podgorica & 185.937 & 7947 & 4,3 & 145.575 & 78,3 & 20.883 & 11,2 & 2458 & 1,3 & 9074 & 4,9 & 8281 & 4,5 & 793 & 0,4 \\
\hline Rožaje & 22.964 & 11 & 0,0 & 1055 & 4,6 & 21.805 & 95,0 & 40 & 0,2 & 53 & 0,2 & 44 & 0,2 & 9 & 0,0 \\
\hline Šavnik & 2070 & 2 & 0,1 & 2007 & 97,0 & 12 & 0,6 & 2 & 0,1 & 47 & 2,2 & 40 & 1,9 & 7 & 0,3 \\
\hline Tivat & 14.031 & 2870 & 20,5 & 9057 & 64,5 & 716 & 5,1 & 184 & 1,3 & 1204 & 8,5 & 988 & 7,0 & 216 & 1,5 \\
\hline Ulcinj & 19.921 & 2196 & 11,0 & 2964 & 14,9 & 14.308 & 71,8 & 148 & 0,7 & 305 & 1,6 & 231 & 1,2 & 74 & 0,4 \\
\hline Žabljak & 3569 & 6 & 0,2 & 3345 & 93,7 & 5 & 0,1 & 96 & 2,7 & 117 & 3,3 & 110 & 3,1 & 7 & 0,2 \\
\hline
\end{tabular}

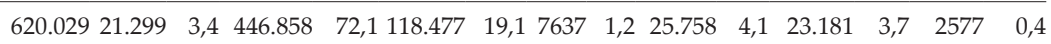

* Objašnjenje kratica: »ukup.«- ukupno; »kat.« - katolici; »prav.«-pravoslavci; »mus.«- muslimani; »ost.«-pripadnici ostalih vjera; »ne.« - zbroj agnostika, ateista, neidentificiranih kršćana i vjerski neizjašnjenih po općinama Crne Gore; »ne.-1«-zbroj agnostika, ateista, neidentificiranih kršćana i vjerski neizjašnjenih koji su se nacionalno izjasnili kao Bosanci, Crnogorci, Jugoslaveni, koji se nisu nacionalno izjasnili ili koji su se regionalno izjasnili; »ne.-2«-zbroj agnostika, ateista, neidentificiranih kršćana i vjerski neizjašnjenih kada se izuzmu oni među njima koji su se izjasnili kao Bosanci, Crnogorci, Jugoslaveni, nacionalno neizjašnjeni ili regionalno izjašnjeni.

Izvori: Tabela O2. Stanovništvo prema nacionalnoj odnosno etničkoj pripadnosti i vjeroispovijesti po opštinama, Popis stanovništva, domaćinstava i stanova u Crnoj Gori 2011. godine, Podgorica, MONSTAT - Uprava za statistiku.

Sukladno rečenome, moglo bi se ustvrditi da je bokeljska slaveno-katolička zajednica i danas podjednako brojna kao i prije sto dvadeset godina, tj. da ima blizu 8500 pripadnika, pri čemu se tek nešto više od polovine izjašnjava Hrvatima. Njezin broj kroz proteklo stoljeće nije rastao zbog iseljavanja, dok je masovnim useljavanjem prvenstveno pravoslavnog življa udio te zajednice u ukupnom stanovništvu Boke Kotorske minoriziran (Crkvenčić i Schaller, 2007). Konkretno, dok je 1900. na teritoriju današnjih općina Herceg Novi, Kotor i Tivat obitavalo oko 30.000 ljudi, 2011. na tom je istom tlu živjelo blizu 68.000 stanovnika (Mrduljaš, 2019). Ako prihvatimo da je i broj autohtonih bokeljskih pravoslavaca ostao razmjerno podjednak broju katolika, moglo bi se zaključiti da danas na prostoru koji zauzimaju navedene tri bokeljske općine doseljenici ili potomci doseljenika čine više od polovine stanovništva.

Napokon, određeni broj slaveno-katoličke populacije koja se u nacionalnom smislu izjasnila Bosancima, Crnogorcima, Jugoslavenima, nacionalno neizjašnjenima ili regionalno izjašnjenima, a u vjerskom kao ateisti, agnosti- 
ci, neidentificirani kršćani ili vjerski neizjašnjeni bio je prisutan i u drugim općinama Crne Gore. Zastupljenost takvih ispitanika mogla je biti znatnija u općinama Budva, Bar, Ulcinj, Nikšić, Cetinje, Danilovgrad te posebice u Podgorici. Stoga ako se broju Hrvata te ostalih Slaveno-katolika koji su očitovali pripadnost katolicizmu pridoda realno mogući broj slaveno-katoličkih Bosanaca, Crnogoraca, Jugoslavena, nacionalno neizjašnjenih i regionalno izjašnjenih osoba koje su se u vjerskom smislu očitovale kao agnostici, ateisti, neidentificirani kršćani ili se uopće nisu očitovale, moglo bi se ustvrditi da je 2011. u Crnoj Gori obitavalo približno 15.000 Hrvata i ostalih pripadnika slaveno-katoličke zajednice (tablica 8). Sukladno tome njezin približan udio u ukupnom stanovništvu Crne Gore iznosio bi oko 2,4\%. Bio bi manji u odnosu na 1921., kada je bio između 3,6\% i 3,9\%, prvenstveno zbog iseljavanja i slabijega prirodnog prirasta $u$ odnosu na pravoslavnu i muslimansku populaciju. Istodobno uvelike bi nadilazio udio izjašnjenih Hrvata (ne računajući pravoslavce koji su popisani kao Hrvati), koji je bio ispod $1 \%$ od ukupnog stanovništva Crne Gore.

Tablica 8. Broj Hrvata i ostalih Slaveno-katolika u Crnoj Gori prema popisu iz 2011.

Table 8. Number of Croats and other Slavic Catholics in Montenegro according to the 2011 census

\begin{tabular}{lcrrrrrrr}
\hline & Maks. br./Popisi* & $\begin{array}{c}\text { God. maks. } \\
\text { br. }\end{array}$ & \multicolumn{2}{c}{ 2011. } \\
\hline Općina & Popis & H. & H.-1961. & H. & SK.-k. & H. + SK.-k. & Ne.-1 \\
\hline Andrijevica & 2011. & 2 & - & 2 & 2 & 4 & 78 \\
\hline Bar & 1971. & 273 & 266 & 244 & 2676 & $\mathbf{2 9 2 0}$ & 1463 \\
\hline Berane & 1961. & 94 & 94 & 39 & 25 & $\mathbf{6 4}$ & 635 \\
\hline Bijelo Polje & 1971. & 67 & 38 & 40 & 21 & $\mathbf{6 1}$ & 462 \\
\hline Budva & 1961. & 185 & 185 & 162 & 125 & $\mathbf{2 8 7}$ & 881 \\
\hline Cetinje & 1961. & 109 & 109 & 40 & 70 & $\mathbf{1 1 0}$ & 657 \\
\hline Danilovgrad & 1961. & 89 & 89 & 53 & 51 & $\mathbf{1 0 4}$ & 703 \\
\hline Herceg Novi & 1961. & 1544 & 1544 & 650 & 578 & $\mathbf{1 2 2 8}$ & 2382 \\
\hline Kolašin & 1971. & 75 & 60 & 7 & 12 & $\mathbf{1 9}$ & 234 \\
\hline Kotor & 1961. & 3483 & 3483 & 1548 & 1012 & $\mathbf{2 5 6 0}$ & 1483 \\
\hline Mojkovac & 1961. & 41 & 41 & 2 & 4 & $\mathbf{6}$ & 240 \\
\hline Nikšić & 1961. & 413 & 413 & 142 & 59 & $\mathbf{2 0 1}$ & 3273 \\
\hline Plav & 1971. & 37 & 19 & 5 & 5 & $\mathbf{1 0}$ & 68 \\
\hline
\end{tabular}




\begin{tabular}{lcrrrrrrr}
\hline & Maks. br./Popisi* & $\begin{array}{c}\text { God. maks. } \\
\text { br. }\end{array}$ & \multicolumn{2}{c}{ 2011. } \\
\hline Općina & Popis & H. & H.-1961. & H. & SK.-k. & H. + SK.-k. & Ne.-1 \\
\hline Plužine & 1971. & 23 & 15 & 2 & & $\mathbf{2}$ & 86 \\
\hline Pljevlja & 1961. & 83 & 83 & 14 & 5 & $\mathbf{1 9}$ & 842 \\
\hline Podgorica & 1971 & 788 & 736 & 628 & 1261 & $\mathbf{1 8 8 9}$ & 8281 \\
\hline Rožaje & $1981 . / 1991$. & 8 & 2 & 6 & 4 & $\mathbf{1 0}$ & 44 \\
\hline Šavnik & 1981. & 15 & 5 & 1 & & $\mathbf{1}$ & 40 \\
\hline Tivat & 1961. & 3423 & 3423 & 2302 & 496 & $\mathbf{2 7 9 8}$ & 988 \\
\hline Ulcinj & 2003. & 77 & 55 & 42 & 417 & $\mathbf{4 5 9}$ & 231 \\
\hline Žabljak & 1971. & 5 & 4 & 2 & 2 & $\mathbf{4}$ & 110 \\
\hline & & & 10.834 & 10.664 & 5931 & 6825 & $\mathbf{1 2 . 7 5 6}$ & 23.181 \\
\hline
\end{tabular}

* Objašnjenje kratica: »maks. br./popisi« - godina popisa tijekom kojeg je u pojedinoj općini Crne Gore zabilježen najviši broj Hrvata između 1961. i 2011; "god. maks. br.« - popis, konkretno iz 1961., tijekom kojeg je utvrđen najviši broj Hrvata u Crnoj Gori između 1948. i 2011.; »H.« - Hrvati (neračunajući 90 pravoslavca koji su popisani kao Hrvati); »SK.-k.«-Slaveno-katolici koji se u popisu 2011. nisu izjasnili Hrvatima, ali koji su očitovali pripadnost katolicizmu; »H. + SK.-k.« - zbroj Hrvata i Slaveno-katolika koji se u popisu 2011. nisu izjasnili Hrvatima, ali koji su očitovali pripadnost katolicizmu; »ne.-1 « - zbroj agnostika, ateista, neidentificiranih kršćana i vjerski neizjašnjenih koji su se nacionalno izjasnili kao Bosanci, Crnogorci, Jugoslaveni, koji se nisu nacionalno izjasnili ili koji su se regionalno izjasnili.

Izvori: Popis stanovništva, domaćinstava i stanova u 1961. godini. Nacionalni sastav stanovništva FNR Jugoslavije (podaci po naseljima i opštinama), knjiga III, Beograd, Savezni zavod za statistiku, 1994; Popis stanovništva, domaćinstava i stanova u Crnoj Gori 2011. godine. Stanovništvo Crne Gore prema polu, tipu naselja, nacionalnoj, odnosno etničkoj pripadnosti, vjeroispovijesti i maternjem jeziku po opštinama u Crnoj Gori, Saopštenje br. 83, Podgorica, Zavod za statistiku, 2011.

\section{ZAKLJUČAK}

Autohtona slavenska katolička populacija (Slaveno-katolici) na prostorima Crne Gore tradicionalno obitava u Boki Kotorskoj, Budvi, Baru i njegovoj okolici. Do 1918. glavninom je pripadala austrijskoj, većinski hrvatskoj i katoličkoj Kraljevini Dalmaciji te je njezino oblikovanje u hrvatskome nacionalnom smislu bilo gotovo ili u potpunosti dovršeno. No nastankom Kraljevine SHS, odnosno Jugoslavije okolnosti se mijenjaju. Od tada se kao manjinska zajednica nalazi duboko unutar sfere u kojoj je dominantan srpski utjecaj, uvelike i nakon 2006., kada dolazi do državnog osamostaljenja Crne Gore, a samim tim i sfere unutar koje zbog opterećenosti hrvatskosrpskih odnosa iskazivanje hrvatske samosvijesti može predstavljati izrazit društveni teret. 
Prema prvom popisu kojim je obuhvaćena populacija svih dijelova današnje Crne Gore, onom iz 1921., na njezinu je tlu živjelo 313.432 stanovnika, od čega između 11.380 i 12.145 Hrvata i ostalih pripadnika slaveno-katoličke zajednice. Tada je njihov udio u ukupnom stanovništvu nastanjenom na prostorima današnje Crne Gore iznosio između 3,6\% i 3,9\%. Popisi nakon 1945. uključuju nacionalnu odrednicu i u njima je, za trajanja socijalističke Jugoslavije (1945. - 1991.), Savezne Republike Jugoslavije odnosno Državne zajednice Srbije i Crne Gore (1991. - 2006.) te napokon u samostalnoj Crnoj Gori (od 2006.) evidentiran sljedeći broj Hrvata: 6808 (1948. godine); 9814 (1953.); 10.664 (1961.); 9192 (1971.); 6904 (1981.); 6244 (1991.); 6811 (2003.); 6021 (2011.).

Već od prvih popisa vidljivo je da se dio Slaveno-katolika u Crnoj Gori ne izjašnjava Hrvatima, prvenstveno u Baru i okolici, gdje će izjašnjavanje u korist nacionalnog crnogorstva trajno prevladavati. Od 1971. veliki dio dotadašnjih, nacionalno očitovanih Hrvata počinje se izjašnjavati Jugoslavenima. Nakon raspada Jugoslavije, u popisima 2003. i 2011. taj vid izjašnjavanja gubi na važnosti. Pritom ne dolazi do povratka u nacionalno hrvatstvo, već do identifikacije s crnogorstvom, odbijanja nacionalnog izjašnjavanja, očitovanja u regionalnom smislu itd. Iz analize koju smo proveli u kontekstu popisa iz 2011. proizlazi da se od ukupne slaveno-katoličke zajednice u Crnoj Gori tek manji dio, tj. 5931 ispitanik, izjasnio Hrvatima (ne računajući pravoslavce koji su popisani kao Hrvati). Istovremeno 29 Bosanaca, 5667 Crnogoraca, 68 Jugoslavena, tri Muslimana, 569 nacionalno neizjašnjenih, 376 regionalno izjašnjenih, 112 Srba i jedan Srbin-Crnogorac očitovali su pripadnost katolicizmu. Za tih se 6825 ispitanika sukladno uvidu u broj autohtone slavenske katoličke populacije na prostorima Crne Gore 1921. te u broj Hrvata u popisima 1953. - 1971. s visokom dozom sigurnosti može ustvrditi da pripadaju slaveno-katoličkoj cjelini.

Ukupni broj slaveno-katoličke populacije u Crnoj Gori 2011. bio je veći od zbroja Hrvata (neračunajući pravoslavce koji su popisani kao Hrvati) i navedenih 6825 osoba, koji je iznosio 12.756, jer mu valja pridodati i određeni broj ispitanika, ponajprije među Bosancima, Crnogorcima, Jugoslavenima, nacionalno neizjašnjenima i regionalno izjašnjenima, koji su se po pitanju vjere očitovali kao agnostici, ateisti, neidentificirani kršćani ili se vjerski nisu izjasnili. Prvenstveno iz komparacije udjela takvih osoba u općinama Boke Kotorske (Herceg Novi, Kotor, Tivat), gdje je on izrazito visok, s udjelima koje imaju u drugim crnogorskim općinama moglo bi se ustvrditi da je ukupni broj izjašnjenih Hrvata te ostalih pripadnika slaveno-katoličke zajednice 2011. iznosio približno 15.000 ili 2,4\% stanovništva Crne Gore. 


\section{LITERATURA}

Banac, I. (1988). Nacionalno pitanje u Jugoslaviji. Zagreb: Globus.

Crkvenčić, I. i Schaller, A. (2005). Boka Kotorska: društveno-političke promjene i razvoj etničkog sastava do 1918. godine, Hrvatski geografski glasnik, 67 (2): 107-122. https:// doi.org/10.21861/hgg.2005.67.02.06

Crkvenčić, I. i Schaller, A. (2007). Promjene etničkog sastava Boke kotorske (1910. - 2003. g.) s posebnim osvrtom na veliko smanjenje broja Hrvata, Hrvatski geografski glasnik, 69 (1): 69-100. https://doi.org/10.21861/hgg.2007.69.01.05

Čubrilović, V. (1959). Seobe i etničke promjene u jugoslavenskim pokrajinama od 15. do početka 19. stoljeća, u: B. Grafenauer i dr. (ur.). Historija naroda Jugoslavije, knjiga 2. Zagreb: Školska knjiga, 840-853.

Ćorović, V. (1995). Istorija Srba. Beograd: Beogradski izdavačko-grafički zavod.

Dubak, B. (ur.) (2011). Crnogorski identitet: zbornik dokumenata o jeziku, narodu i vjeri. Podgorica: IIC Narodne stranke, Narodna misao - Matica srpska, Društvo članova u Crnoj Gori.

Ivković, F. (1991/1992). Organizacija uprave u Dalmaciji za vrijeme druge austrijske vladavine 1814-1918., Arhivski vjesnik, 34-35: 31-51.

Jovanović, S. (2016). Bilansi nezavisnosti, Matica crnogorska, 17 (67): 31-42.

Kulišić, Š. (1980). O etnogenezi Crnogoraca. Titograd: Pobjeda.

Lisac, J. (1996). Hrvatski dijalekti i jezična povijest. Zagreb: Matica hrvatska.

Ljetopis popa Dukljanina (1988). Beograd: Prosveta - Srpska književna zadruga.

Marković, S. (1974). O postanku i razvoju crnogorske nacije. Titograd: Grafički zavod.

Marković, S. (2014). Stanovništvo srednjovjekovnog Bara. Prerast: NIP »Gospa od Škrpjela«.

Mirić, D. (2000). Ukupno kretanje broja Hrvata u Srbiji i Crnoj Gori od 1948. do 2000. godine, Društvena istraživanja, 9 (4-5): 743-767.

Mišetić, R. (2018). O Hrvatima u Boki Kotorskoj u vrijeme osamostaljenja Crne Gore, u: R. Mišetić i M. Katušić (ur.). Demografske promjene i kulturna baština Hrvata Boke Kotorske: zbornik radova. Zagreb: Hrvatsko katoličko sveučilište, 179-198.

Mrduljaš, S. (2019). Etnički sastav naselja Boke Kotorske prema popisu stanovništva iz 1900. godine, Migracijske i etničke teme, 35 (3): 241-276. https://doi.org/10.11567/ met.35.3.1

Pasinović, M. M. (2005). Hrvati u Crnoj Gori - s posebnim osvrtom na Boku Kotorsku i drugu polovicu XX. stoljeća. Kotor - Rijeka: Hrvatsko građansko društvo Crne Gore - Adamić.

Peričić, E. (1991). Sclavorum regnum Grgura Barskog. Zagreb: Kršćanska sadašnjost.

Prekić, A. (2019). Crnogorska istoriografija i nacionalizam, u: A. Duranović (ur.). Ogledi o historiografiji i nacionalizmu u Jugoistočnoj Evropi: zbornik radova. Sarajevo: Udruženje za modernu historiju, 51-77.

Rastoder, Š. (1991). Dr. Nikola Dobrečić: arcibiskup barski i primas srpski 1872-1955. Budva: Mediteran.

Stančić, N. (2002). Hrvatska nacija i nacionalizam u 19. i 20. stoljeću. Zagreb: Barbat.

Šufflay, M. (1925). Srbi i Arbanasi. Beograd: Izdanje seminara za arbanasku filologiju.

Vizantijski izvori za istoriju naroda Jugoslavije, tom II. (1959). Beograd: Vizantološki institut. 
Vizantijski izvori za istoriju naroda Jugoslavije, tom III. (1966). Beograd: Vizantološki institut.

Živković, T. (2012). Neretljani - primer razmatranja identiteta u ranom srednjem veku, Istorijski časopis, knjiga 61: 11-25.

\section{IZVORI}

Definitioni rezultati popisa stanovništva od 31. januara 1921. god., Sarajevo, Kraljevina Jugoslavija, Opšta državna statistika, 1932.

Nacionalni sastav stanovništva SFR Jugoslavije 1981. (podaci po naseljima i opštinama), knjiga I, Beograd, Savezni zavod za statistiku, 1991, http://publikacije.stat.gov.rs/G1981/ Pdf/G19814001.pdf (20. 05. 2021.).

Popis stanovništva, domaćinstava $i$ stanova u 1961. godini. Nacionalni sastav stanovništva FNR Jugoslavije (podaci po naseljima i opštinama), knjiga III, Beograd, Savezni zavod za statistiku, 1994, http://publikacije.stat.gov.rs/G1961/Pdf/G19614001.pdf (20. 05. 2021.).

Popis stanovništva, domaćinstava $i$ stanova u 2003. Stanovništvo: nacionalna ili etnička pripadnost - Podaci po naseljima i opštinama, Podgorica, Zavod za statistiku, 2004.

Popis stanovništva, domaćinstava i stanova u Crnoj Gori 2011. godine. Stanovništvo Crne Gore prema polu, tipu naselja, nacionalnoj, odnosno etničkoj pripadnosti, vjeroispovijesti i maternjem jeziku po opštinama u Crnoj Gori, Saopštenje br. 83, Podgorica, Zavod za statistiku, 2011.

Popis stanovništva i stanova 1971. Stanovništvo - etnička, prosvetna i ekonomska obeležja stanovništva $i$ domaćinstava prema broju članova (rezultati po opštinama), knjiga VI, Beograd, Savezni zavod za statistiku, 1994, http://publikacije.stat.gov.rs/G1971/Pdf/ G19714001.pdf (20. 05. 2021.).

Stalno stanovništvo po narodnosti po popisu od 15. marta 1948. godine, Beograd, 1954, http:// publikacije.stat.gov.rs/G1948/Pdf/G19484001.pdf (20. 05. 2021.).

Stanovništvo prema nacionalnoj pripadnosti 1991., Beograd, Republički zavod za statistiku, http://publikacije.stat.gov.rs/G1991/Pdf/G19914021.pdf (20. 05. 2021.)

Tabela CG5. Stanovništvo prema nacionalnoj odnosno etničkoj pripadnosti i vjeroispovijesti, Popis stanovništva, domaćinstava i stanova u Crnoj Gori 2011. godine, Podgorica, MONSTAT - Uprava za statistiku, https://www.monstat.org/ cg/ page.php?id=535\&pageid=322 (20. 05. 2021.).

Tabela O2. Stanovništvo prema nacionalnoj odnosno etničkoj pripadnosti i vjeroispovijesti po opštinama, Popis stanovništva, domaćinstava i stanova u Crnoj Gori 2011. godine, Podgorica, MONSTAT - Uprava za statistiku, https://www.monstat.org/cg/page. php?id=535\&pageid $=322$ (20.05. 2021.).

Ukupno stanovništvo po narodnosti - popis 1953., Beograd, Republički zavod za statistiku, http://publikacije.stat.gov.rs/G1953/ Pdf/G19534001.pdf (20. 05. 2021.). 


\title{
Share of the Croatian population in Montenegro according to the 1948-2011 censuses
}

\author{
Saša Mrduljaš
}

\begin{abstract}
SUMMARY
The majority of Croats in Montenegro are the native population traditionally living in the Bay of Kotor, the town of Budva and Bar and its surroundings. A minority of them are immigrants or their descendants. As early as during the Austro-Hungarian rule over the Montenegrin coast, and especially during the Yugoslav period, they inhabited the area of today's Montenegro, mostly its inland towns. This paper primarily aims to present and analyse the size of the Croatian population in Montenegro in general and at the level of its administrative units. To do so, it uses data from the censuses conducted from 1948 to 2011, which recorded national affiliation, among other things. In the context of those censuses, one can argue that, during their conduct, it was possible to declare oneself as a Croat, and that a major share of the population avoided declaring themselves as such although they could, based on their ethnic characteristics.
\end{abstract}

Accordingly, the second aim of the paper was to attempt to determine, in the context of the 2011 census, which is a source of plenty of relevant data, not only the number of declared Croats but also those who were undeclared as such, but could certainly be considered to belong to the same linguistic, religious and cultural community as Croats. For this paper, that wider unit was termed the Slavic Catholic community (Slavic-Catholic), which is already recognised in language as the Central South Slavic area (Croatia, Bosnia and Herzegovina, Serbia, Montenegro), among other things as a certain "opposite" of the Slavic-Orthodox and Slavic-Muslim communities of the same spatial scope. To better understand the position of Croats in Montenegro, and especially their reluctance to declare Croatian national affiliation, which is more and more evident over time, an integral part of the paper is an appropriate presentation of historical circumstances that have framed their past and present identity positioning.

The first data on the presence of Croats in today's Montenegrin area refers to the period of Slavic settlement of South-east Europe, which took place until the beginning of the 7th century. According to the work of the Byzantine emperor Constantine Porphyrogenitus (945-959), "On the Governance of the Empire", during their settlement, Croats occupied the former Roman province of Dalmatia (which, according to the author, "started from the surroundings of Durrës and Bar and stretched to the Istrian mountains and to the river Danube in width"), as well as Pannonia and Illyricum. According to the Chronicle of the Priest of Duklja, probably written by the (Arch)Bishop of Bar Gregory in the period 1177-1189, upon settlement the Slavs had founded a state, the backbone of which was on the coast, between Istria and today's northern Albania. According to the Chronicle, that coastal belt was divided into White and Red Croatia, which stretched from Duvanjsko Polje further south. Besides, Byzantine 11th- and 12th-century writers mention Croats and Croatia in the context of the area of today's Montenegro.

However, from the beginning of the 9th century, that is, the point in time from which one can continuously follow the political development in the Adriatic-Dinaric belt, 
or the area of the former Roman Dalmatia, it is certain that four smaller Slavic principalities existed between the rivers Cetina and Bojana: Neretva, Zahumlje, Travunia and Duklja. In the mid 11th century, Duklja, Travunia and Zahumlje were united into a state at the initiative of the rulers of Duklja. The expanded state of Duklja, ruled by the Vojislavljević dynasty, gained international acknowledgement since the papacy recognised it as a separate kingdom and a strong lever for maintaining its own identity, manifested in the existence of a state religious centre in the form of the Catholic metropolis of Bar. Such circumstances could have suggested the emergence of a much wider state unit, located approximately between the rivers Neretva and Drim on the one side and the Adriatic and the river Tara on the other, which would have implied the formation of an ethnic body.

However, events unfolded in a different direction. Since the mid 12th century the state of Duklja had been losing ever more power, completely falling under the ruler of neighbouring Orthodox Serbia at the end of the same century. During that time the Schism of 1054 acquired full significance. The 1204 establishment of the Latin Empire, with its seat in Constantinople, led to a strong polarisation between Catholicism and Orthodoxy. In such conditions, upon establishment of its own church in 1219 , the Serbian dynasty of Nemanjić began to carry out mass Orthodoxisation of the Zahumlje and Duklja areas to ensure their loyalty. Primarily exposed to religious conversion were Slavic Catholic people, who, at that time, shared many similarities with the neighbouring Orthodox in the entire area of the Adriatic-Dinaric belt in terms of external manifestations of their Christian identity, significantly marked by the tradition of Cyril and Methodius. Coastal, communal centres in the area of today's Montenegro, Kotor, Budva and Bar, at the time still largely Romanesque, but eventually Slavicised, and their "belonging" or gravitating Slavic population, as well as the Albanian population located next to gradually Albanianised Ulcinj, along the river Bojana and in Malesia, were left Catholics.

The territorial relations between Catholics and Orthodox established at the time have largely remained relevant until modern times. In the area of today's Montenegro, the Slavic Catholic population was in principle reduced to a distinct minority concentrated in and around the coastal communes. As the Serbian state weakened from the mid 14th century, those communes gradually merged with the western states, and ultimately with the Venetian Republic. They remained under its rule until the end of the 18th century. After that, they were mainly part of the Austrian Kingdom of Dalmatia until 1918. Under those conditions, sharing the social climate with the population of the eastern Adriatic coast, who spoke the same language and shared the same religion, from the mid 19th century the Slavic Catholic population of today's Montenegrin coast became involved in the processes leading to the constitution of the Croatian nation.

The political and social development of the Orthodox population in Montenegro took a different course. By integrating into the de facto Serbian Orthodox Church, they began acquiring Serbian ethnic characteristics. However, given the disintegration of the Serbian state on a part of today's Montenegrin territory, a new state emerged in the form of Zeta, centred in sub-Lovćen Montenegro and ruled by the Balšić dynasty and the Crnojević dynasty. During the Ottoman rule, which began in the late 15th century, sub-Lovćen Montenegro retained a certain autonomy, which became the basis for the formation of the Montenegrin state close to its current borders in the late 17th century. While the Montenegrin population "remained" in the identity sphere of proto-national Serbs due to Orthodoxy, imbued with the cult of the Nemanjić 
dynasty, its peculiar development enabled them to acquire own ethnic consciousness. The dichotomy between the Montenegrin and Serbian sense of identity has not been overcome to this day, which is becoming increasingly clear in the division of the Orthodox population between the national Montenegrins and the national Serbs.

With the disintegration of Austro-Hungary and the emergence of the Kingdom of Serbs, Croats and Slovenes, that is, Yugoslavia, the Slavic Catholic population in the area of today's Montenegro found itself permanently separated from the political, or at least administrative framework defined by the Catholic majority, after almost five hundred years. Instead, it became a distinct minority group in an environment that was continuously exposed to strong Serbian influences, even after Montenegro gained independence. Over time, following the processes of migration towards the coast, it also became a minority in settlements where it once represented the only or majority population. Under those conditions, strongly marked by latent or real contradictions in the relations between Croats and Serbs and often radical manifestations of Serbian identity in their environment, for the Slavic Catholic population in Montenegro, the declaration of Croatian identity became a kind of burden that not everyone was ready or able to bear. In that context, among other things, it is worth looking at the data presented, which points to a decline in the share of Croats in Montenegro. Equally, attention should be paid to the data from the 2011 census, which indicates a kind of mass declaration of "alternative" forms of ethnicity on the part of the Slavic-Catholic population.

According to the first census, the one of 1921, which covered the population of all parts of today's Montenegro, 313,432 inhabitants lived on its soil, of which between 11,380 and 12,145 were Croats and other members of the Slavic-Catholic community. According to that census, which took no account of the national determinant, but recorded the religious and linguistic ones, the share of members of that community in the total population inhabiting the area of today's Montenegro was between $3.6 \%$ and $3.9 \%$. The censuses after 1945 , which, as pointed out, covered the national determinant and were conducted in socialist Yugoslavia (1945-1991), Federal Republic of Yugoslavia / the State Union of Serbia and Montenegro (1991-2006) and in independent Montenegro (since 2006) recorded the following shares of Croats in Montenegro: 6,808 (in 1948), 9,814 (in 1953), 10,664 (in 1961), 9,192 (in 1971), 6,904 (in 1981), 6,244 (in 1991), 6,811 (in 2003), and 6,021 (in 2011).

It is evident from the first censuses that part of the Slavic-Catholics in Montenegro did not declare themselves as Croats. This is primarily the case in Bar and its surroundings, where the declaration of Montenegrin nationality has permanently prevailed. Since 1971, a large number of people formerly declared as Croats began to declare themselves as "Yugoslavs". Following the disintegration of Yugoslavia, in the 2003 and 2011 censuses, that type of declaration lost significance. However, no "return" to the declaration of Croatian national affiliation occurred, but rather the adoption of Montenegrin identity, rejection of the declaration of nationality, declaration of regional affiliation, etc. The analysis conducted in the context of the 2011 census shows that only a small part of the total Slavic-Catholic community in Montenegro declared themselves as Croats. Basically, only 5,931 people did so, if the total share of Croats $(6,021)$ is reduced by 90 Orthodox who are probably registered as Croats for family reasons. At the same time, 29 Bosnians, 5,667 Montenegrins, $68 \mathrm{Yu}-$ goslavs, three Muslims, 569 nationally undeclared persons, 376 regionally declared persons, 112 Serbs and one Serb Montenegrin declared their affiliation with Catholicism. According to the insight into the share of the native Slavic Catholic population 
in Montenegro in 1921 and the share of Croats in the 1953-1971 censuses, it can be stated with a high level of certainty that those 6,825 respondents belonged to the Slavic Catholic population.

The total share of the Slavic Catholic population in Montenegro in 2011 was larger than the sum of Croats $(5,931)$ and the mentioned 6,825 persons, which amounted to 12,756 , given that it should be increased by a certain number of respondents, primarily among Bosnians, Montenegrins, Yugoslavs, nationally undeclared and regionally declared who declared themselves as agnostics, atheists, unidentified Christians or refused to declare their religion. Primarily based on a comparison of the share of such persons within the municipalities of Boka Kotorska (Herceg Novi, Kotor, Tivat), where it is extremely high, with their shares in other Montenegrin municipalities, it could be argued that in 2011, the total share of Croats and other members of the Slavic-Catholic community amounted to approximately 15,000 or $2.4 \%$ of the population of Montenegro.

KEY WORDS: Croats, Montenegro, Kingdom of Dalmatia, Yugoslavia, censuses 